UNIVERSIDADE DE SÃO PAULO

FACULDADE DE ECONOMIA, ADMINISTRAÇÃO E CONTABILIDADE DEPARTAMENTO DE ADMINISTRAÇÃO

PROGRAMA DE MESTRADO PROFISSIONAL EM

EMPREENDEDORISMO

PROCESSO DE DECISÃO ESTRATÉGICA EM UMA EMPRESA

EMPREENDEDORA:

UM ESTUDO DE CASO DA EMPRESA CIAO MAO

Daniel Tomoki Hayashi

Orientador: Prof. Dr. Martinho Isnard Ribeiro de Almeida

VERSÃO CORRIGIDA

SÃO PAULO 
Prof. Dr. Marco Antonio Zago

Reitor da Universidade de São Paulo

Prof. Dr. Adalberto Américo Fischmann

Diretor da Faculdade de Economia, Administração e Contabilidade

Prof. Dr.Roberto Sbragia

Chefe do Departamento de Administração

Prof. Dr. Martinho Isnard Ribeiro de Almeida

Coordenador do Programa de Mestrado Profissional em Empreendedorismo 


\title{
PROCESSO DE DECISÃO ESTRATÉGICA EM UMA EMPRESA EMPREENDEDORA: \\ UM ESTUDO DE CASO DA EMPRESA CIAO MAO
}

\author{
Dissertação apresentada ao Programa de \\ Mestrado Profissional em Empreendedorismo \\ do Departamento de Administração da \\ Faculdade de Economia, Administração e \\ Contabilidade da Universidade de São Paulo, \\ como requisito parcial para a obtenção do \\ título de Mestre em Ciências.
}

Orientador: Prof. Dr. Martinho Isnard Ribeiro de Almeida

VERSÃO CORRIGIDA

SÃO PAULO 
FICHA CATALOGRÁFICA

Elaborada pela Seção de Processamento Técnico do SBD/FEA/USP

Hayashi, Daniel Tomoki

Processo de decisão estratégica em uma empresa empreendedora: um estudo de caso da empresa Cia Mao / Daniel Tomoki Hayashi. -- São Paulo, 2017.

$99 \mathrm{p.}$

Dissertação (Mestrado) - Universidade de São Paulo, 2017.

Orientador: Martinho Isnard Ribeiro de Almeida.

1. Tomada de decisão 2. Empreendedorismo 3. Design 4. Inovação I. Universidade de São Paulo. Faculdade de Economia, Administração e Contabilidade. II. Título.

CDD -658.403 


\section{RESUMO}

O presente estudo tem como objetivo analisar o processo de tomada de decisão de um empreendedor de sucesso, desde a decisão de criação da empresa até a sua implementação, identificando as boas práticas realizadas. A empresa estudada foi a Ciao Mao, marca de calçados brasileira fundada em 2007, que teve destaque ao conquistar diversos prêmios de design no Brasil e exterior e obter reconhecimento por seu caráter inovador, sendo considerada em publicações especializadas como um dos grandes destaques do empreendedorismo nacional. A empreendedora em questão, Priscila Callegari, continua na direção executiva da organização desde sua criação e é a principal tomadora das decisões estratégicas. Por essa empresária ter uma formação em design e não em administração, o processo de criação da empresa não seguiu com rigor nenhum modelo de administração estratégica, porém foi notável o processo estruturado de pensamento em suas tomadas de decisões e uma habilidade em gerar soluções inovadoras, sendo este o grande fator motivador para o presente trabalho. Seguindo a proposta de um mestrado profissional, o trabalho faz uma análise da prática para a teoria, tendo natureza exploratória e abordagem qualitativa. A metodologia utilizada foi a de um estudo de caso único realizado em profundidade com um observador participante, sendo este o próprio autor do trabalho que também ocupa o cargo de gerente comercial e marketing da Ciao Mao desde 2009. A análise verificou convergências e divergências entre as teorias de tomada de decisão estratégica e o caso prático, assim como identificou afinidades com as teorias de design thinking e design estratégico. Observou-se que uma empresa empreendedora tem desafios diferentes de uma grande corporação. Ao tratarmos do processo de tomada de decisão, um empreendedor tem a vantagem de possuir mais liberdade nas suas escolhas, porém tem o desafio de assumir os riscos integralmente, em especial com produtos inovadores, onde a previsibilidade de resultados é baixa e os riscos são inerentes. Dado a restrição de recursos de um empreendedor, o desafio em toda decisão estratégica foi viabilizar a existência da empresa sem perder o senso do possível, ou seja, vislumbrando novas soluções criativas e assumindo riscos de forma consciente. A análise do caso mostrou que nem sempre a solução ideal é a solução viável. Os estudos de teorias de design demonstraram que uma das principais contribuições do designer é sua capacidade de identificar necessidades não atendidas ou mal atendidas e a partir desse conhecimento gerar soluções criativas para solucioná-las com os recursos disponíveis. Outro fator identificado foi a importância do preparo para a criação de um negócio sustentável. Através do estudo realizado também se concluiu que uma das principais habilidades da empreendedora foi ser uma líder agregadora. A empresária tinha autoconhecimento das suas competências e limitação, e soube otimizar os diversos elos da cadeia de valor articulando os envolvidos para um objetivo comum. Para isso buscou entender os impactos que suas decisões tinham a cada um dos participantes dessa rede e desenvolveu soluções criativas agregando valor em cada um dos elos. O trabalho traz como contribuição principal a descrição de uma série de práticas adotadas pela empresária no processo de tomada de decisão estratégica que podem servir de inspiração para outros empreendedores.

Palavras-Chave: tomada de decisão, empreendedorismo, design, inovação 


\begin{abstract}
The present study has the purpose of analyzing the decision-making process of a successful entrepreneur and identifing good practices adopted by this professional. The case studied is of a Brazilian footwear brand, Ciao Mao, founded in 2007. The enterprise has won five design awards in Brazil and abroad and it was considered one of the greatest highlights of Brazilian innovative entrepreneurship by several specialized publications. The entrepreneur, Priscila Callegari, has been the executive director of the organization since its start, therefore she is the main responsible for the decision-making of every strategy of the company. She didn't have a Business Administration background, she has graduated and worked as a designer her whole career, therefore the company in its creation did not strictly followed any strategic management model. However, there was evidences that she had a structured thinking process in her decision-making that generated innovative solutions. Following the proposal of a professional master's degree, the paper made an analysis from practice to theory. It has an exploratory nature, a qualitative approach and it used the methodology of a single case study in depth with a participant observer. The author of this research holds the position of sales and marketing manager of Ciao Mao in the past eight years. The analysis verified convergences and divergences between theories of strategic decision-making and the practical case, as well as it identified affinities with theories of design thinking and strategic design. The study of the case showed that when dealing with the decision-making process, an entrepreneur had the advantage of having more freedom in her choices, but she had the responsibility of taking full risk for every decision. This matter is especially important when dealing with innovative products which has low predictability of results. Every strategic decision taken by the entrepreneur had to be well thought and bring new creative solutions while taking risks in a conscious way. Since she had restricted resources of time, team and money, the viable solution was not always the ideal one. The study showed that one of the main contributions of a designer in an organization is her ability to identify unmet needs and generate creative solutions to solve them with the available resources. The analysis also concluded that one of the main skills of the studied entrepreneur was her ability to be an aggregator leader. The entrepreneur had self-knowledge of her skills and limitation, and knew how to optimize the various links in the value chain by articulating all those parties involved to a common goal. To do this, she had to understand the impacts that her decisions had on each one of the participants of this network and she developed creative solutions adding value in each of the links. The main contribution of the work is the description of a series of practices adopted by this businesswoman in the process of strategic decision making that can serve as inspiration for other entrepreneurs.
\end{abstract}

Keywords: decision-making, entrepreneurship, strategic design, innovation 


\section{SUMÁRIO}

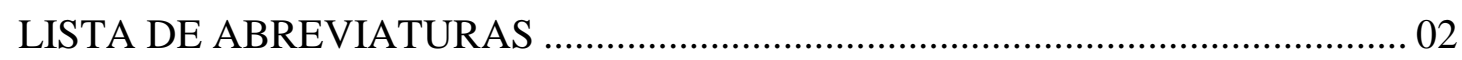

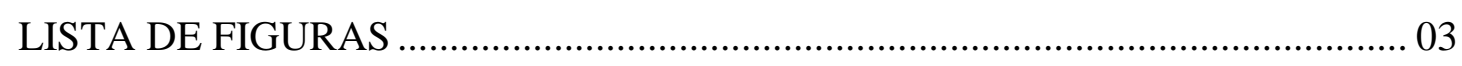

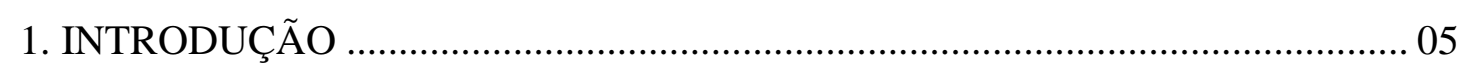

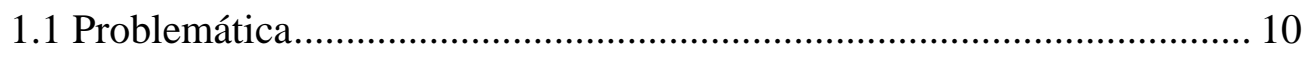

1.2 Questão de Pesquisa ............................................................................. 11

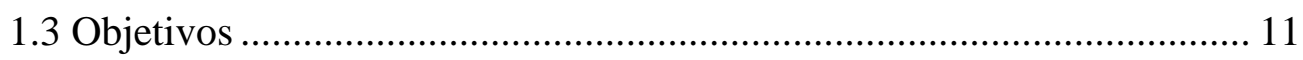

1.3.1 Objetivo Principal................................................................ 11

1.3.2 Objetivos Secundários ........................................................... 11

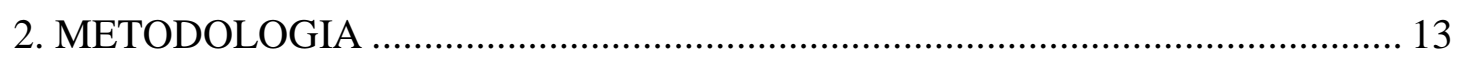

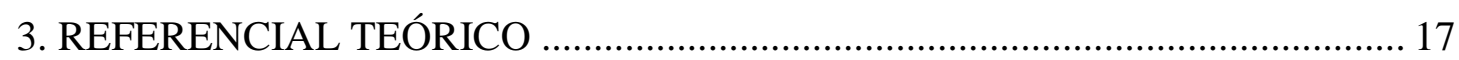

3.1 Decisão Estratégica ......................................................................... 17

3.2 Design na Adminsitração ............................................................... 19

3.3 Particularidades de pequenas e médias empresas no processo de tomada de decisão estratégica ................................................................ 21

3.4 Modelo de desenvolvimento de estratégia em uma empresa ................ 22

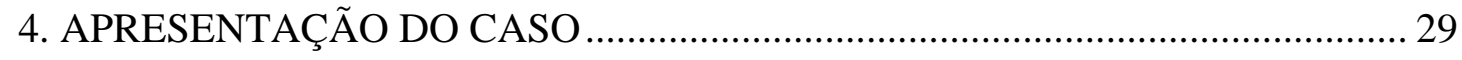

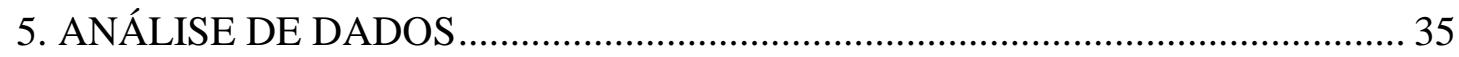

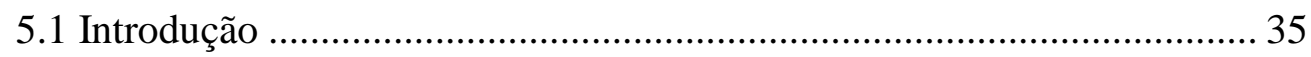

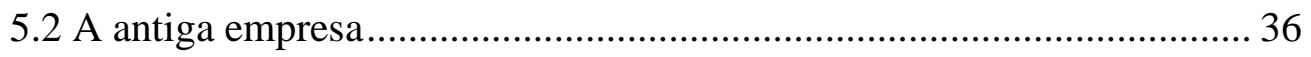

5.3 Escopo de Atuação ............................................................................ 38

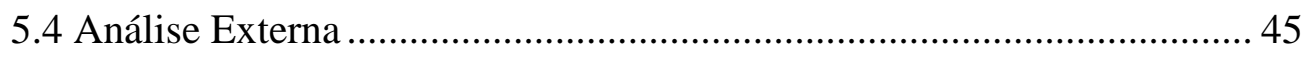

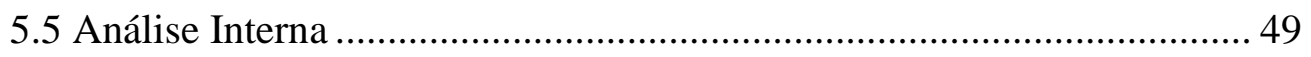

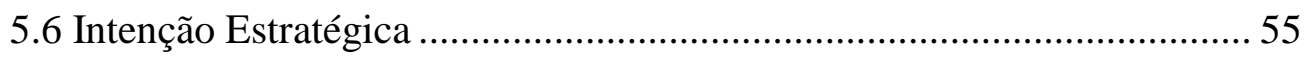

5.7 Posicionamento Estratégico ............................................................. 58

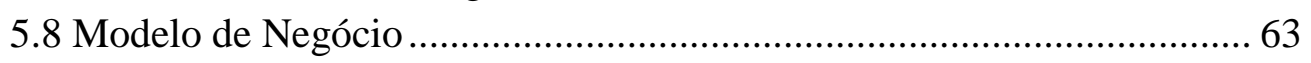

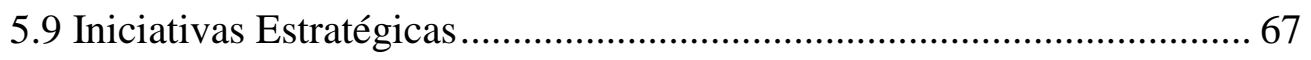

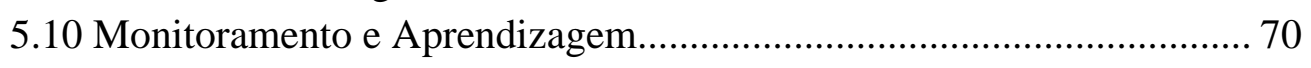

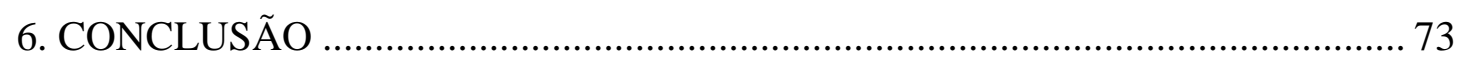

7. LIMITAÇÕES E SUGESTÕES PARA ESTUDOS FUTUROS ............................ 81

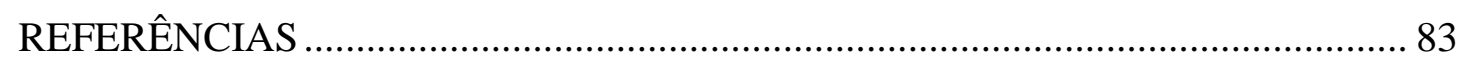

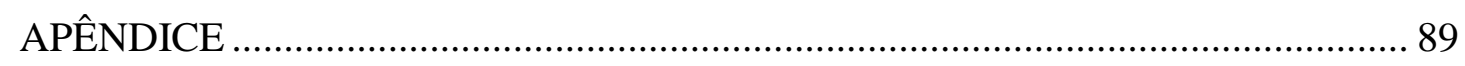


LISTA DE ABREVIATURAS

ABEST: Associação Brasileira de Estilistas

ABICALÇADOS: Associação Brasileira da Indústria Calçadista Brasileira

GEM: Global Entrepreneurship Monitor

SEBRAE: Serviço Brasileiro de Apoio às Micros e Pequenas Empresas

SENAI: Serviço Nacional de Aprendizagem Industrial 


\section{LISTA DE FIGURAS}

Figura 1 - Capa do livro da KPMG: "Todo mundo disse que não ia dar certo" 09

Figura 2 - Modelo Racional de Herbert Simon ............................................................ 18

Figura 3 - Modelo geral de gestão estratégica........................................................... 24

Figura 4 - Ciao Mao na exposição Design Brasileiro Fronteiras no MAM-SP .......... 30

Figura 5 - Loja Ciao Mao em São Paulo ………………………………………….... 30

Figura 6 - Conceito de Calçados Interativos ............................................................ 32

Figura 7 - Priscila visita uma das fábricas de solados ............................................... 32

Figura 8 - Diversos modelos de calçados da Ciao Mao ……………………………... 34

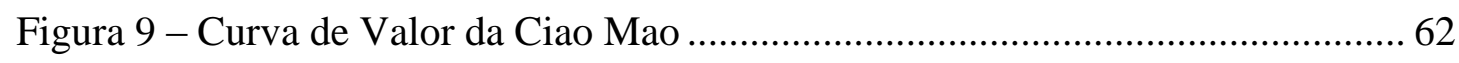




\section{INTRODUÇÃO}

A criação de uma empresa empreendedora parte majoritariamente do esforço individual do seu idealizador - o empreendedor. Esse processo envolve uma sequência de tomadas de decisões estratégicas desde a definição da proposta de valor, até local de atuação, capital a ser investido e seleção de equipe. Mintzberg (1983) destaca que o empreendedor é a figura na organização que reúne as habilidades de: alocador de recursos, para manter o equilíbrio entre as necessidades organizacionais e seus objetivos; e de negociador, dotado de autoridade e conhecimento tanto de nível interno quanto externo para a tomada de decisões da organização. Drucker (1987) afirma que o empreendedor busca a mudança criando algo novo, sendo inovador e transformando valores. Consegue ainda viver com as incertezas e riscos que um negócio comporta. Ademais, o empreendedor sabe aproveitar as oportunidades que não são necessariamente vistas pelas outras pessoas.

Segundo relatório de 2014 sobre o empreendedorismo no Brasil desenvolvido pelo Global Entrepreneurship Monitor (GEM), 24\% das novas empresas não chegam a completar dois anos de vida. Em um estudo complementar chamado Causa Mortis: o sucesso e o fracasso das empresas nos primeiros 5 anos de vida realizado pelo Serviço Brasileiro de Apoio às Micros e Pequenas Empresas do estado de São Paulo (SEBRAE- SP, 2014), são 3 as principais causas de mortalidade de uma empresa: (a) falta de planejamento prévio, (b) má gestão e (c) o comportamento do empreendedor. Essa última causa, à primeira vista, pode parecer um fator mais subjetivo, mas na prática tem enorme influência no sucesso ou fracasso de uma empresa, já que é nesse indivíduo que se concentra a tomada de decisões estratégicas.

Conforme apontado por Huang (2009), os desafios para esse gestor são enormes, dado que uma empresa iniciante tem uma série de limitações: verbas restritas, equipe pequenas, acesso limitado a consultorias ou tecnologias. Essas limitações fazem com que cada decisão estratégica da empresa dependa muito de um processo individual de pensamento do empreendedor. Quando observada por terceiros, muitas vezes essas decisões parecem intuitivas, em especial quando envolvem soluções criativas e inovadoras.

As teorias de administração oferecem diversas ferramentas para o auxílio de tomada de decisões estratégicas que devem ser estudadas para seu uso em empresas empreendedoras, como as teorias de planejamento estratégico e de tomada de decisão. 
Pode-se entender que o empreendedor é um articulador, um líder agregador, ele tem uma visão individual que precisa que se torne coletiva, esse indivíduo tem como função juntar partes interessadas e convergir seus esforços a um objetivo comum. Esse desafio se torna ainda mais complexo no mundo atual, pois, segundo Cardoso, autor de Design para um mundo complexo, a complexidade está relacionada ao grau de dificuldade de prever as interrelações potenciais entre as partes. (2013, p.25). O autor ainda defende que em um mundo inundado de informações, não existem receitas formais capazes de equacionar os desafios da atualidade, mas sugere um questionamento sobre os problemas a serem enfrentados. Ele sugere, como um primeiro passo, abdicar da premissa de que os problemas são simples. Cardoso faz uma provocação ao afirmar que se alguém tem uma resposta pronta, é provável que não tenha entendido direito a pergunta.

Rafael Cardoso (2013) ainda resgata a máxima da metodologia de projetos que diz ser essencial aprofundar a análise do problema, antes de propor soluções. O segundo passo é abandonar a premissa de que os problemas são insolúveis. Para ele uma das grandes vantagens de reconhecer a complexidade do mundo é compreender que todas as partes estão interligadas. Desta forma, as ações de cada um juntam-se as ações dos demais para formar movimentos que estão além das capacidades individual de cada parte componente desta rede. Para o autor, a crescente complexidade dos problemas demanda soluções coletivas (2013, p. 43).

Este papel agregador do empreendedor em busca de soluções coletivas é fundamental e pode ser auxiliado pelas teorias de design. Segundo Cardoso (2013), a grande relevância do design tem sido ajustar conexões entre coisas antes desconexas para gerar novas soluções e para se atingir os resultados desejados, todos os envolvidos devem compreender que a parte de cada um é entender a sua parte do todo.

O empreendedor deve então ter a habilidade de entender o comportamento das partes envolvidas - fornecedores, funcionários e clientes - sendo esta uma habilidade que a tecnologia ainda não consegue replicar. Segundo Jagdish Parikh em Intuição: a nova fronteira da administração (1994, p.50): “[...] os computadores só podem (até o momento) computar, e uma dependência absoluta de sistemas analíticos de solução de problemas leva ao que é conhecido como paralisia de análise.”. O autor defende a importância dos administradores no cenário atual de constate mutação, assumindo áreas que não podem ser 
automatizadas ou computadorizadas. Parikh defende então a importância da intuição. Se, para o autor, antigamente recorria-se a intuição por causa da escassez de dados e de informações disponíveis, atualmente, a tecnologia nos dá acesso a tantos dados, que mesmo para selecionar as informações relevantes, o uso da intuição se torna essencial. Assim sendo, por mais que haja apoio da tecnologia, a tomada de decisão ainda é um processo humano. $\mathrm{O}$ autor complementa:

\footnotetext{
O poder da nossa tecnologia sobre o mundo orgânico do qual viemos é o poder de repetir. Apenas por meio da repetição é que dominamos o mundo à nossa volta. Dominamos a Terra porque pudemos repetir os nossos esforços até atingirmos os nossos objetivos. No mundo da natureza nada se repete, a não ser de maneira muito geral. No mundo da tecnologia, nada funciona se as coisas não se repetirem de uma forma muito específica. (PARIKH, 1994, p. 76)
}

Essa capacidade de tomar decisões sobre situações novas, improvisar, é a grande que habilidade humana, é aquela que a tecnologia ainda não consegue reproduzir.

Um mundo com desafios novos, exige que o empreendedor tome decisões criativas e inovadoras. Parikh questiona a eficiência do ensino da administração focada apenas em teorias analíticas e quantitativas, pois, segundo ele, essas teorias formam excelentes analistas, mas não profissionais capazes de criar e de fazer uma empresa crescer. Segundo ele, estas teorias estão baseadas em ensinar soluções apropriadas para solucionar problemas antigos, aplicando-as a problemas atuais. Isso não faz mais sentido no mundo contemporâneo em que os problemas mudam drasticamente em curtos períodos de tempo. Não há precedentes ou paralelos a serem estudados, tudo acontece concomitantemente, assim como precisa ser a tomada de decisão do empreendedor $(1994$, p.80).

Um empreendedor deve tomar decisões estratégicas que direcionem a empresa para ter eficácia, mais do que a simplesmente a busca de eficiência. Segundo Almeida (2010, p.5): “[...] as pessoas são eficientes ao desenvolver bem um processo e eficazes ao alcançar bons resultados.". Pensando na sobrevivência de uma empresa, seria como um nadador em alto mar, ele pode nadar muito rápido, ter eficiência, mas precisa saber a direção certa para nadar, ter eficácia. De nada adianta nadar rápido se estiver indo para longe da costa, a sua morte será iminente, o mesmo se aplica a uma empresa que está sendo gerida sem eficácia.

A eficácia é por tanto, atender as necessidades da empresa, porém para isso é necessário entender o cenário complexo que vivemos, onde as empresas não agem isoladamente, elas fazem parte de uma rede que envolve desde clientes e funcionários, até fornecedores e demais parceiros. 
É necessário então que o empreendedor seja esse líder agregador, um articulador da eficácia da rede, de modo a maximizar a satisfação das necessidades de todos os participantes do processo. O melhor para o cliente, pode não ser o melhor para o fornecedor, é preciso encontrar esse ponto de equilíbrio: não basta conseguir uma redução de custo com o fornecedor, se esse não conseguir manter isso de forma viável para uma relação duradoura, ao mesmo tempo que se o fornecedor não conseguir reduzir seu custo a um valor adequado, o produto final não terá um preço viável e o cliente não irá comprar. O que tornará toda a cadeia irrelevante, não haverá eficácia, pois não se atingirá os bons resultados esperados. O empreendedor assim deve estar constantemente tomando decisões que equacionem essa satisfação de necessidades dos envolvidos na cadeia.

Considerando alguns temas citados anteriormente como: os desafios de uma empresa empreendedora, o processo de formação de estratégia e o uso dos conhecimentos do design na criação de soluções inovadoras, o presente trabalho, explorou o caso da empresa brasileira de calçados, Ciao Mao, No estudo foi analisado o processo de decisão estratégica da empreendedora, Priscila Callegari, com o intuito de identificar lições aprendidas nas suas práticas que a levaram ao sucesso de sua empresa. A Ciao Mao completou em 2017 dez anos de existência e reconhecimento no mercado, ao todo foram cinco prêmios de design nacionais e internacionais: IDEA/BRASIL 2008 (ouro), IDEA 2008 (bronze), TOP XXI 2009 (1lugar), BRAZIL DESIGN AWARD 2010 e Prêmio Direções 2010 da ABICALÇADOS (Associação Brasileira de Calçados) na categoria Design e em 2017 um prêmio de destaque em internacionalização de marca também pela ABICALÇADOS. A empreendedora participou de quatro bienais de design, dezenas de entrevistas para emissoras de TV e publicações impressas, assim como foi selecionada como um dos 20 destaques do empreendedorismo brasileiro pela consultoria KPMG (2015), sendo a única representante feminina deste grupo. 


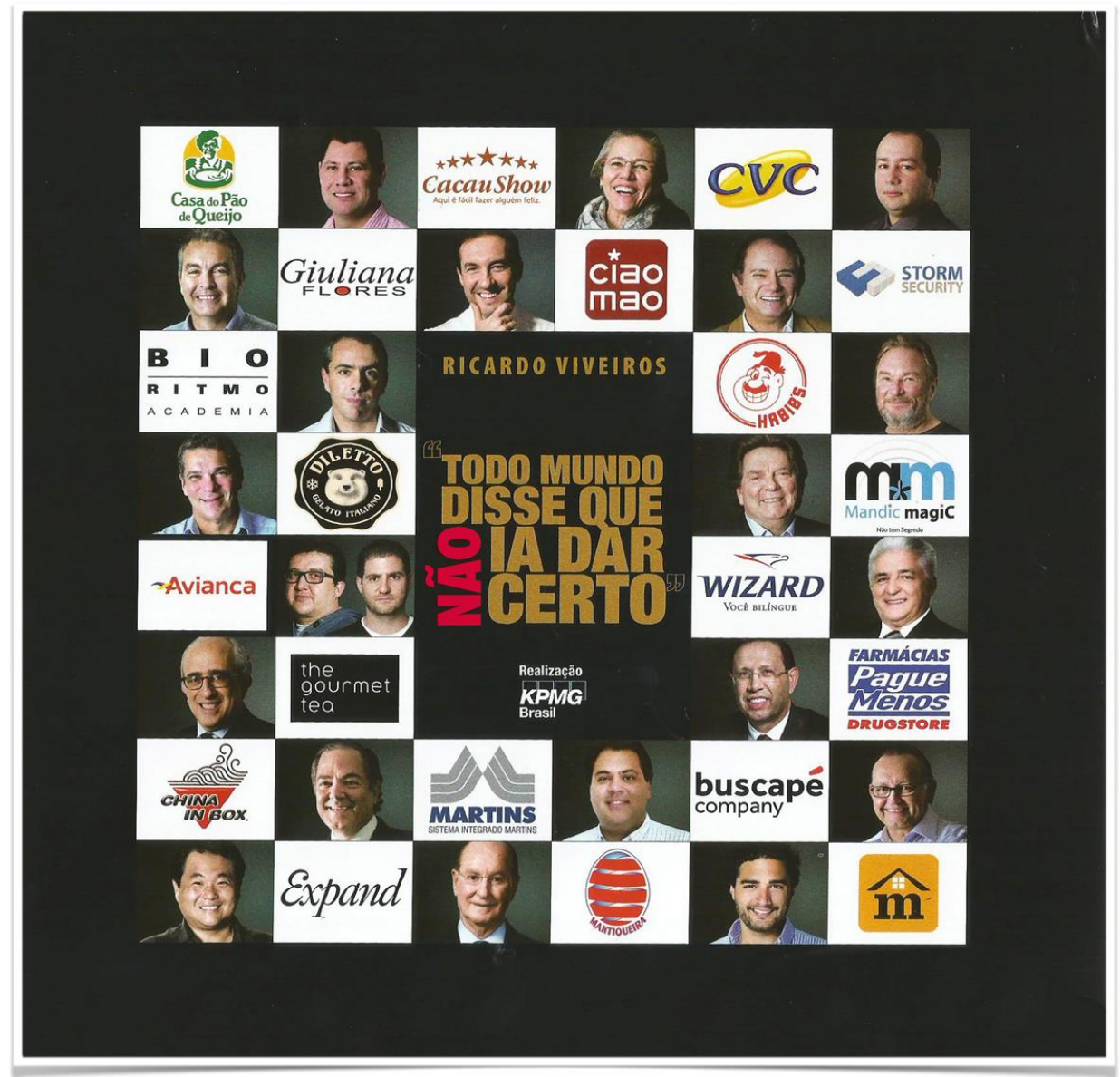

Figura 1 - Capa do livro da KPMG: "Todo mundo disse que não ia dar certo" FONTE: VIVEIROS, 2014, capa

A empresa também foi selecionada pelo SEBRAE-SP em 2010 na publicação 99 Soluções Inovadoras. Segundo o Manual de Oslo:

Uma inovação é a implementação de um produto (bem ou serviço) novo ou significativamente melhorado, ou um processo, ou um novo método de marketing, ou um novo método organizacional nas práticas de negócios, na organização do local de trabalho ou nas relações externas" (MANUAL DE OSLO,1997, p.55).

Este trabalho buscará entender o processo mental que essa líder utiliza para a tomada de suas decisões estratégicas. 


\subsection{Problemática}

$\mathrm{O}$ autor do presente trabalho ocupa cargo de gerência nas áreas comercial, marketing e planejamento na empresa desde 2009 tendo acompanhado e apoiado todos os principais processos de decisões estratégicas desde então, o que possibilita o desenvolvimento de um estudo de prática para a teoria conforme proposto pelo mestrado profissional.

Durante esse período o autor participou das definições e execuções de diversas ações como: abertura das 3 lojas próprias da marca (definição de mercado, negociação, estudo de viabilidade, contratação de equipe, definição de projeto arquitetônico), formatação de parceria para participação em semanas de moda, participação em feiras do setor de moda e design, contratação de toda a equipe de escritório e loja, treinamento de equipes, contratação e acompanhamento de consultorias estratégicas, avaliação, negociação e acompanhamento de parcerias produtivas, planejamento financeiro, planejamento de mix de produtos, definição de metas para as equipes comerciais. Por ser uma empresa de pequeno porte em crescimento, o autor teve oportunidade de vivenciar ativamente do processo de decisão para essas ações juntamente com a empreendedora.

Neste processo, o autor identificou uma alta capacidade da empreendedora em tomar decisões bem-sucedidas frente aos diversos problemas enfrentados na empresa. Não apenas na criação de produtos, mas também em negociação com fornecedores, gestão de pessoas e demais desafios. O autor pode notar um processo de tomada de decisão diferente de gestores com formações administrativas tradicionais com os quais ele havia trabalhado anteriormente. Muitas dessas decisões eram criativas e inovadoras, fato muito nítido no processo de desenvolvimento da proposta de valor da empresa. Em uma análise inicial, essas decisões pareciam uma simples capacidade intuitiva individual, ou o que alguns chamavam de talento, mas ao observar com um olhar mais rigoroso e vislumbrando teorias de administração e de design, via-se ali uma convergência de processos, não sendo resultado do acaso. Tendo isso em vista, o autor identificou os questionamentos a serem estudados com possíveis contribuições para os conhecimentos atuais de teoria da decisão estratégica.

- Existe um método para a tomada de decisões da empreendedora?

- Como sistematizar este processo e identificar práticas benéficas para outros empreendedores? 


\subsection{Questão de Pesquisa}

Quais as lições aprendidas com o caso da empreendedora da CIAO MAO na formação de estratégia de uma empresa?

\subsection{Objetivos}

\subsubsection{Objetivo Principal}

Identificar lições aprendidas nas práticas de tomada de decisão de uma empreendedora durante o processo de formação de estratégia de sua empresa.

\subsubsection{Objetivos Secundários}

- Descrever as lições aprendidas a partir de um modelo de um modelo teórico de formação de estratégia.

- Apresentar as contribuições para formação de estratégia para outros empreendedores a partir das lições aprendidas identificadas. 


\section{METODOLOGIA}

Recomenda-se para um mestrado de cunho profissional, a utilização da experiência prática como ponto de partida, que depois será confrontada com teorias da administração com rigor acadêmico. O resultado dessa interação de conhecimento, visa validar tanto as teorias acadêmicas quando postas em uma situação prática, como também verificar como a experiência real poderia ter sido melhor administrada se houvesse a utilização consistente do conhecimento acadêmico. Como conclusão deste trabalho, se almeja sugerir melhorias nas teorias existentes e gerar conhecimento documentado com validade científica, que pode ser utilizado tanto pela empresa em questão como por outras empresas que podem se inspirar nessa experiência.

Tendo as considerações acima descritas, o método definido para esta dissertação será o estudo de caso realizado de forma qualitativa e exploratória para um caso único. Yin defende a relevância de um projeto de caso único, ao invés de casos múltiplos, quando "o pesquisador tem acesso a uma situação previamente inacessível à observação científica. Vale a pena, portanto, conduzir um estudo de caso, porque a informação descritiva por si só será reveladora" (YIN, 2001, p.64).

A definição de Scramm (1971) para estudo de caso, revela a adequação da escolha desta estratégia de pesquisa. $\mathrm{O}$ autor definiu que a essência de um estudo de caso, é que ela tenta esclarecer uma decisão ou um conjunto de decisões: a razão pela qual foram tomadas, como foram implementadas e quais foram os resultados. Ou seja, se alinha com o tema central deste presente trabalho: o processo de tomada de decisão.

Fortalecendo a opção por esse método de estudo, Yin (2001) define que o estudo de caso é uma investigação empírica que analisa um fenômeno contemporâneo dentro do seu contexto de vida real. Ou seja, não dissocia o fenômeno de seu contexto, permite uma investigação preservando as características holísticas e significativas dos acontecimentos da vida real, neste caso os processos organizacionais de uma empresa existente, Ciao Mao, e as tomadas de decisões da empreendedora Priscila Callegari. Essa profissional lidera uma empresa há 10 anos no mercado e neste período obteve grande reconhecimento através de cinco prêmios de design, um prêmio de destaque em estratégia de internacionalização de marca, além de publicações do SEBRAE-SP (2010), na qual foi considerada uma das principais soluções 
inovadoras daquele ano, e da KPMG (2013) em que também foi selecionada como umas das 20 empreendedoras mais relevantes do país.

O estudo de caso é uma estratégia de pesquisa abrangente, segundo Yin (2001), a investigação de um caso enfrenta uma situação em que haverá mais variáveis de pesquisa do que pontos de dados, assim sendo, precisa se basear em várias fontes de evidências. O autor complementa que o estudo pode se beneficiar do desenvolvimento prévio de proposições teóricas para conduzir a coleta e análise de dados.

Antes de iniciar a coleta de dados, Yin (2001) defende a importância do desenvolvimento da teoria. Mesmo sendo um estudo investigativo de um caso prático, a etapa de estudo da teoria permite uma direção para o projeto de pesquisa ao determinar quais dados devem ser coletados e as estratégias da análise desses dados.

Para este estudo, será utilizado como principal referência teórica o trabalho Modelos de Negócios e suas aplicações em administração de Caldeira (2016). Deste trabalho, focou-se no capítulo em que o autor explora um modelo de formação de estratégia de empresa. Os 8 pontos principais de constituição da empresa sugeridas pelo autor serviram como direção para o desenvolvimento do projeto desde sua coleta de dados até a análise do caso.

O estudo em questão é exploratório, como descrito por Selltiz (1974), esse tipo de estudo é adequado quando o pesquisador tem como objetivo familiarizar-se com um determinado fenômeno ou conseguir uma nova compreensão deste, neste caso o processo de tomada de decisão estratégica de uma empreendedora. O autor ainda afirma que o planejamento de pesquisa precisa ser suficientemente flexível, de modo a permitir a análise de muitos aspectos diferentes do fenômeno.

Selltiz (1974) também argumenta que na maioria dos casos apenas uma pequena proporção do conhecimento e das experiências são colocadas em forma escrita, se tornando importante para as pesquisas de relações humanas a observação de efeitos de ações e decisões tomadas pelas pessoas em experiências cotidianas. Essa definição se torna especialmente interessante, por estarmos tratando de uma dissertação de mestrado profissional, em que o pesquisador está inserido no seu objeto de pesquisa. Assim a sua experiência cotidiana aliada a uma pesquisa acadêmica busca trazer novas conclusões e contribuições para os estudos de administração de empresas. 
Quanto a escolha da pessoa a ser estudada, Selltiz (1974) sugere que o pesquisador deve procurar ideias provocantes e intuições úteis e não a estatística da profissão. Desta forma, a pessoa deve ser escolhida devido a sua possibilidade de oferecer a contribuição procurada. Foi com este pensamento que se optou pelo estudo do processo de decisão da empreendedora, Priscila Callegari. A designer e empresária trouxe soluções inovadoras para o mercado em que se inseriu, alcançando reconhecimento do mercado e da indústria.

Na etapa de coleta de dados para estudos de caso, Yin (2001) ressalta a importância de um pesquisador experiente com a capacidade de conduzir com qualidade a interação entre questões teóricas que estão sendo estudadas e os dados a serem coletados, pois este será capaz de tirar vantagens de oportunidades inesperadas.

Os dados primários foram obtidos através de entrevista pessoal, individual e em profundidade com a criadora e proprietária da empresa Ciao Mao, Priscila Callegari. Esta profissional, como fundadora e dirigente, é a principal tomadora de decisão da empresa. A entrevista foi realizada de forma semi-estruturada, conforme roteiro disponível no apêndice I.

Segundo Flick (2004), esse tipo de pesquisa com dados verbais possui um planejamento prévio, mas sem a rigidez de uma entrevista padronizada. O pesquisador tem uma linha condutora de temas centrais, mas utiliza perguntas abertas permitindo uma exploração do conhecimento do entrevistado sobre o assunto e uma flexibilidade no aprofundamento de questões que o pesquisador identificar como importantes para o estudo. A entrevista foi realizada de forma individual e em profundidade. Conforme sugerido por Bauer e Gaskell (2002), o pesquisador preparou um tópico guia cobrindo os principais temas do estudo. No início da entrevista foram feitos comentários introdutórios sobre a pesquisa para a entrevistada, assim como notificando que a entrevista seria gravada. Foi também informado que a qualquer momento o entrevistado poderia interromper a entrevista ou solicitar não responder alguma das perguntas.

Os dados secundários foram obtidos através de pesquisa documental: arquivos da empresa, relatórios e apresentações, assim como matérias e entrevistas divulgadas pela mídia. Serão analisadas também publicações ligadas a empreendedorismo, design, indústria calçadista e de moda. 
O trabalho utilizou também o storytelling, como metodologia para análise da trajetória empreendedora e momentos de tomada de decisão estratégica. Segundo, Gonçalo (2013), o storytelling pode ser um modo de transmitir conhecimento de altos níveis de complexidade de modo simples. Histórias têm a habilidade de transmitir em linguagens simbólicas uma grande quantidade de conhecimento ou informação de modo sucinto. As histórias contadas representam as ações organizacionais, podendo se identificar: a memória organizacional, o contexto que a empresa se encontrava no momento, expressões de valores, conhecimentos e atitudes, assim como ser uma forma de transferência do conhecimento tácito para o explícito. A análise dessas histórias permite identificar padrões no exercício de atividades cotidianas que podem ter representação no método de tomada de decisão que pretendesse estudar.

Após identificadas as principais decisões estratégicas adotadas pela empreendedora, se comparará os processos observados com as teorias de tomadas de decisão e modelagem de estratégia empresarial. Com base nessas informações serão propostas práticas para a tomada de melhores decisões estratégicas. 


\section{REFERECIAL TEÓRICO}

\subsection{Decisão estratégica}

Simon, no seu livro A Razão das Coisas Humanas (1989), diz que o processo de administrar é feito de tomada de decisões e, assim sendo, tomar decisões e administrar são atividades equivalente.Segundo Bataglia (2009), a decisão é um comprometimento específico de uma ação, normalmente restringida por uma limitação de recursos. Já o processo decisório é o conjunto de ações e fatores dinâmicos que começam com a identificação de um estímulo inicial, problema, e terminam quando se define um comprometimento de qual ação será tomada em relação ao estímulo inicial identificado.

Bataglia (2009) define uma decisão como sendo estratégica para a organização quando há um grande comprometimento dos recursos utilizados, ações de grande impacto para o curso da organização e não há situações precedentes iguais. Para Simon (1960), o processo decisório estratégico é não-estruturado, ou seja, "é novo, incerto e não ocorreu anteriormente, não tendo um conjunto explícito e predeterminado de respostas ordenadas na organização." (Bataglia, 2006, p.34).

Buchanan (2006) diz que o estudo da tomada de decisão é uma mescla de várias disciplinas do saber como sociologia, psicologia, matemática, economia e ciências políticas. Para ele a filosofia refletiria o que uma decisão revela sobre nosso eu e nossos valores. A história trataria das decisões tomadas pelos líderes em momentos críticos. Enquanto que o estudo de risco e do comportamento organizacional nasce de um desejo mais prático, o de ajudar o administrador a obter melhores resultados.

Sabe se que há grandes limitações na tomada de decisões, seja de tempo, conhecimentos ou recursos, e assim sendo o processo decisório é imperfeito. Buchanan (2016) ainda coloca que o risco é parte indissolúvel de qualquer decisão, em especial tratando-se de decisões estratégicas que tem maior impacto para a organização e envolvem custos de oportunidade, a abdicação de "caminhos não tomados".

Há diversas formas de abordagem do processo de decisão. Martins (2013) descreve os principais como sendo: (1) Racional de Simon, (2) Racionalidade Limitada também de Simon, (3) Incrementalista de Lindblom e Quim, (4) Desestruturado de Mintzberg e (5) Lata de Lixo de Cohen, March e Olsen. 
O modelo do processo de tomada de decisão mais difundido é o modelo racional de Herbert A. Simon, que foi resumido no trabalho de Martins (2013) em, quatro etapas, conforme figura 2.

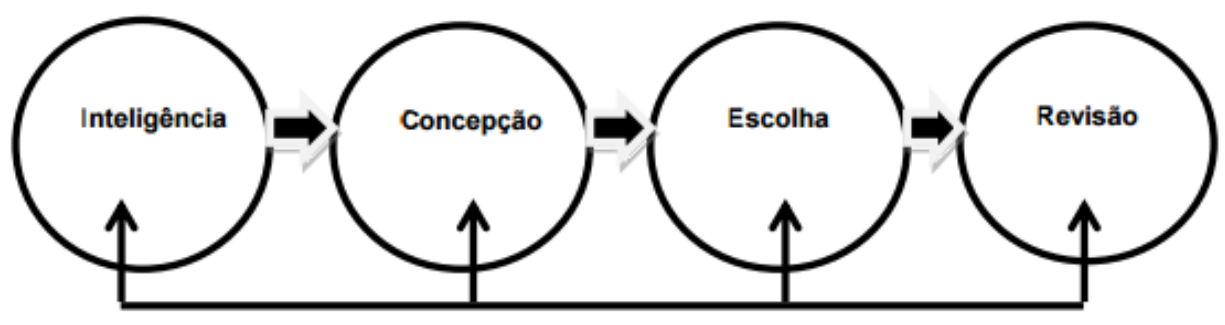

Figura 2 - Modelo Racional de Herbert Simon

FONTE: MARTINS (2013, p.29)

- A primeira etapa é a da inteligência ou investigação, momento em que é explorado o ambiente onde os dados são trabalhados em busca de problemas e oportunidades.

- Na etapa da concepção, ou desenho, ocorre a criação, desenvolvimento e análise dos possíveis cursos de ação a serem tomadas.

- Na etapa de escolha ocorre a seleção de uma das alternativas de ação.

- Na etapa de revisão ocorre a avaliação de decisões passadas. Importante considerar que entre qualquer uma das etapas o decisor pode revisitar a etapa anterior visando melhorar a alternativa na busca de uma solução que melhor satisfaça seus objetivos.

No trabalho de Solino e El-Aouar (2001), os autores trazem um estudo de outros modelos de tomada de decisão, entre eles o modelo racional proposto por Stoner e Freeman (1992) que também se divide em quatro etapas:

- Exame da situação: etapa em que ocorre a definição do problema, identificação dos objetivos da decisão e diagnóstico da causa. Se assemelha bastante a etapa de inteligência proposta no modelo de Simon.

- Criação de alternativas: que os autores destacam que devem ser criativas;

- Avaliação e seleção de alternativas: elegendo a mais adequada para a situação; 
- Implementação e monitoramento da decisão: etapa que envolve o planejamento da implementação da ação, a aplicação do plano e o acompanhamento das implementações, devendo-se também realizar os devidos ajustes.

Há uma grande similaridade entre os dois modelos, mas a diferença mais significativa fica na quarta etapa, em que Stoner e Freeman destacam a importância da implementação da ação e não apenas a escolha dela.

É importante enfatizar que na teoria a melhor decisão pode ser tomada se tendo todas as informações necessárias, mas isso raramente ocorre no decorrer da vida de uma organização, neste contexto vemos a importância do pensamento de racionalidade limitada de Simon (1989), que destaca que a tomada de decisão dos administradores é baseada majoritariamente em informações inadequadas, uma vez que as organizações não possuem recursos financeiros nem tempo hábil para que possam colher todas as informações necessárias para uma tomada de decisão plenamente racional. Outros fatores que limitam a perfeita decisão racional são: a limitação das habilidades de obtenção e avaliação de dados pelos integrantes da organização, base de informações incompletas, capacidade de avaliação de uma quantidade limitada de alternativas e impossibilidade de cálculo de valores efetivos para cada resultado das alternativas propostas. Cabe assim ao responsável pela tomada de decisão a opção de escolher aquela que mais o satisfaz dentro deste contexto de limitações.

Ackoff (1998) ressalta o grande desafio dos administradores lidarem com o excesso de informações do cenário atual, tornando cada vez mais difícil a previsão de resultados racionais para cada alternativa.

\subsection{Design na Administração}

Huang (2009) aponta que a formação educacional do empresário influencia diretamente a forma como ele faz a gestão de sua empresa. A empreendedora, Priscila Callegari, é uma designer por formação, partindo-se desse pensamento, foi realizada uma pesquisa para levantar algumas convergências existentes entre os estudos de administração e design em especial no que tange o processo da tomada de decisão de um projeto. 
O conceito de design é complexo e abrangente. Segundo Nitzche (2012) o design é tão múltiplo que ainda não tem uma definição. Para Borges (2003), este conceito não é uma ciência exata, tangível e mensurável. Já Simon (1989) argumenta que a ciência do design é um processo parte analítico e científico e parte experimental, pois valoriza tanto o uso dos sentidos para a percepção do mundo como o fator subjetivo da intuição. Bono (2008) defende que as ciências naturais se ocupam de como as coisas são e que o design se interessa por como as coisas deveriam ser. Seguindo este pensamento, o design seria relevante para qualquer cenário onde as rotinas não estejam funcionando da sua melhor forma, tendo-se a oportunidade de gerar um ambiente novo, mais adequado para a vida humana.

Apesar deste papel amplo e crucial do design, Borges (2003) analisa que a palavra se disseminou nas últimas décadas com um significado reducionista, sendo associada a coisas caras, frescas e com um "visual arrojado", sendo interpretado muitas vezes apenas como apelo estético, associações que não condizem com o seu original significado.

Na década de 1980, Gorb (1986) já iniciava tentativas práticas de ensinar a metodologia do design para os gestores de empresa. Segundo Nitzche (2012), independente da indústria em que se atua, o maior risco de um gestor é confiar inteiramente na gestão analítica. Pelo medo de se enfrentar a ambiguidade, as empresas correm o risco de perder o senso do possível. $\mathrm{O}$ autor argumenta que as empresas precisam perceber que é possível gerenciar processos abertos aos insights criativos, processos que não seguem uma linha reta e que à primeira vista podem parecer perda de tempo. Para ele, é o nervosismo diante do problema que gera uma pressa congelante que elimina as condições necessárias para a criatividade florescer. É neste cenário que o design thinking se torna relevante, o processo de design oferece uma maneira de manter as coisas em movimento sem um fechamento prematuro, uma capacidade de compreender a ambiguidade das mudanças e perceber que elas são oportunidades criativas, não sementes para a paralisia.

Baseado na literatura estudada, pode se concluir que o design thinking é um processo mental de uso intencional da criatividade associada a uma visão analítica holística de modo a atender uma necessidade identificada. Assim sendo, o primeiro passo para uma empresa é treinar sua capacidade de percepção de necessidades não atendidas, então analisar o cenário, as partes envolvidas, e as ferramentas e recursos disponíveis. O planejamento e a solução criativa para 
atender uma necessidade identificada utilizando de forma coerente os recursos acessíveis é a prática do design thinking.

Alguns dos autores estudados buscam definir metodologias para o design thinking, associando-o diretamente a geração de inovação. Tom Kelley, por exemplo, define cinco passos: compreender, observar, analisar, visualizar, avaliar e implementar (Nitzche, 2012). Já Ambrose e Harris, em seu livro Design Thinking (2011) sugerem um modelo de sete passos: definir, pesquisar, idear, prototipar, selecionar, implementar e aprender.

Há ainda autores que separam o design thinking do chamado design estratégico. Segundo Stuber (2012), o design thinking é mais conhecido como as múltiplas tentativas de se tentar reproduzir a forma de pensamento de designers e arquitetos, é um termo entendido como uma metodologia para solução de problemas, em que se coloca o ser humano no centro do processo. Já o design estratégico é uma metodologia que considera o design como ferramenta importante para a elaboração de estratégias da empresa, e possuiu como finalidade principal o desenvolvimento de um sistema produtivo, que leva em conta toda a cadeia de valor. Ou seja, não pensar apenas no usuário final, mas na elaboração das soluções estratégias levando-se em consideração os demais stakeholders: funcionários, fabricantes, meio ambiente, entidades governamentais e a própria empreendedor.

\subsection{Particularidades de pequenas e médias empresas no processo de tomada de decisão estratégica}

Krakaeur (2011) destaca algumas características particularidades sobre o processo de tomada de decisões estratégicas em empresas de pequeno e médio porte, baseada em um estudo de Huang (2009):

- As decisões são tomadas majoritariamente pelo proprietário com pouca colaboração ou interferência de restante do grupo.

- Há uma preferência por buscar informações fora da empresa ao invés de dentro, destacando a importância da rede de relacionamento do empresário. 
- Poucos são os empresários que se dedicam a desenvolver alternativas para tomar decisões estratégicas. Esses empresários costumam respondem rapidamente a oportunidades, mas ficam limitados nas formas de aproveitá-las.

- Esses empresários recorrem constantemente a imitação da concorrência para a tomada de decisões estratégicas.

- A intensidade como as pequenas e médias empresas analisam as informações do seu ambiente afetam na tomada de decisão.

- A formação educacional do empresário reflete na forma como ele faz a gestão de sua empresa.

- O processo de decisão estratégica de empresas de menor porte envolve diretamente as características pessoais do empresário.

O estudo de Huang (2009) foi realizado com empresas chinesas, mas autores de outros países convergem com várias de suas ideias como por exemplo, Xavier e Cancellier (2008) que também acreditam na influência das características pessoais do proprietário da empresa no processo de tomada de decisão e Smith (1998) que identificou que o processo de tomada de decisão de empresas pequenas costuma ser informal.

\subsection{Modelo de desenvolvimento da estratégia de uma empresa}

Existem diversos modelos de desenvolvimento de estratégias de uma empresa, no trabalho de Pedroso (2016) são compilados alguns dos principais autores que abordaram esse tema. Barney e Hesterly (2008) elaboraram um conjunto sequencial de análises e escolhas baseada em 6 etapas:

- definição da missão;

- determinação dos objetivos;

- análise externa;

- análise interna; 
- escolhas estratégicas;

- implantação da estratégica.

Já Saloner, Shepard e Podolny (2001) definiram 7 etapas:

- identificação da estratégia;

- avaliação da estratégia;

- desenvolvimento das opções estratégicas;

- avaliação das opções estratégicas;

- seleção da estratégia;

- comunicação da estratégia;

- implantação.

Temos também sugestões que envolvem ciclos maiores, como o de Grant (2003) que sugere um ciclo de 9 etapas:

- definição das diretrizes do planejamento estratégico, metas e premissas dos cenários e previsões;

- elaboração do rascunho do plano de negócio;

- discussão com a corporação;

- revisão final do plano de negócios;

- elaboração do plano anual;

- definição do plano corporativo;

- aprovação pela diretoria/conselho;

- determinação de metas de desempenha anual;

- e avaliação desempenho. 
Lafley e Martin (2013) apresentam um processo focado em apenas 5 etapas apresentadas como questões que a empresa deve responder:

- Qual a nossa aspiração vitoriosa?

- Onde iremos atuar?

- Como nós seremos bem-sucedidos nos mercados escolhidos?

- Quais as capacidades organizacionais devem estar disponíveis para sermos bemsucedidos?

- Quais os sistemas de gestão são necessários?

Pedroso (2016) observou que não havia um consenso único para a elaboração de estratégia de uma empresa, mas que a literatura convergia para uma sequência de etapas iterativas que permitia uma organização de pensamento na elaboração de uma estratégia empresarial. $\mathrm{O}$ autor então elaborou um modelo de gestão da estratégia (figura 3).

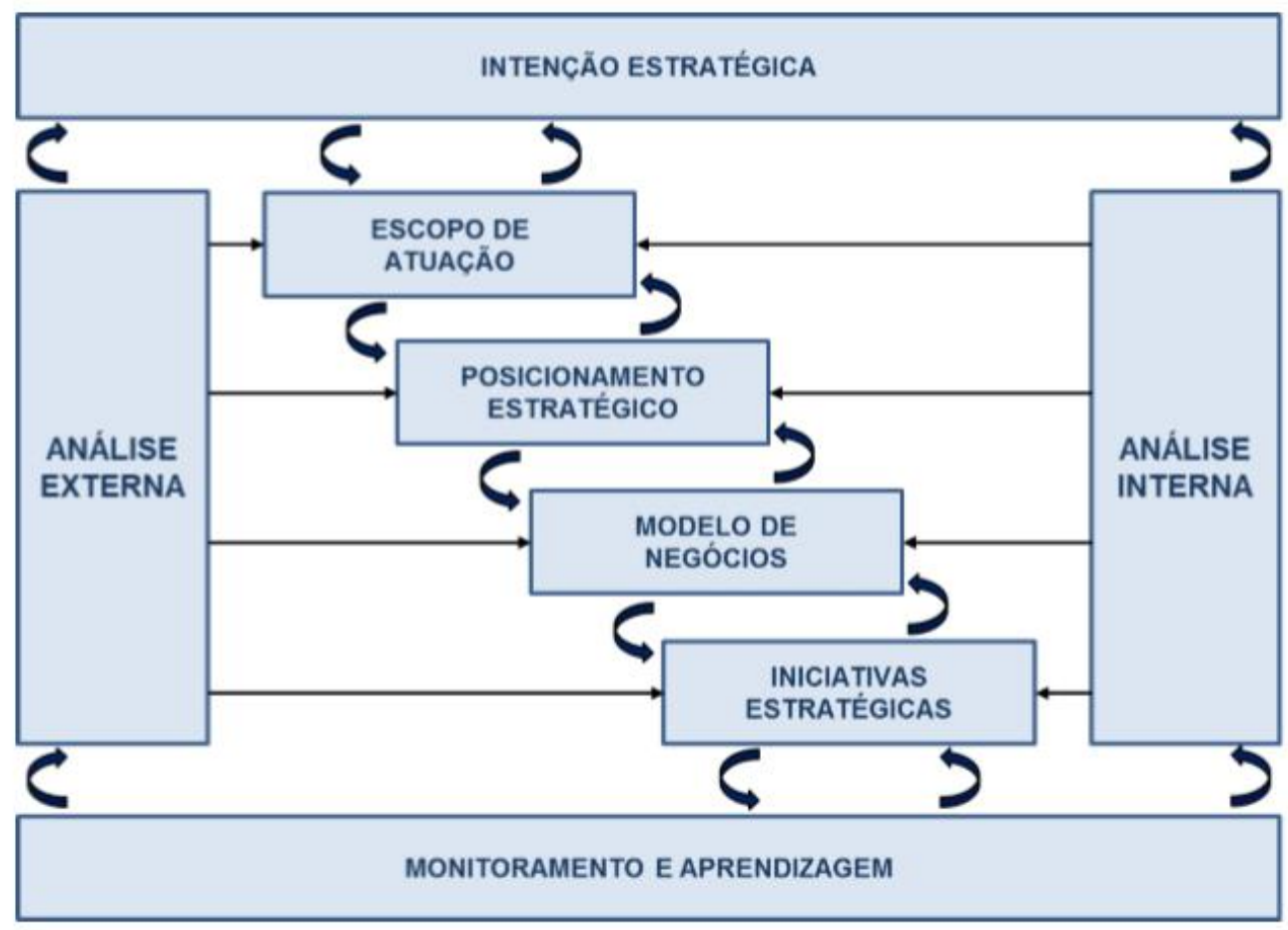

Figura 3 - Modelo geral de gestão estratégica FONTE: PEDROSO, 2016, p. 109 
As oito etapas apresentadas foram nomeadas e descritas pelo autor como:

1. Intenção estratégica: reflete os propósitos e as aspirações de uma organização. Formado pela tríade: missão, visão e valores.

A missão deve expressar o propósito principal da empresa. E responde as seguintes questões: por que a empresa existe? Qual é a sua contribuição para a sociedade? Se a empresa não existisse, ou deixasse de existir, qual diferença faria para o mundo?

A visão se referente a onde a empresa quer chegar, qual a sua posição futura almejada.

E essa visão é que deve ser o foco da atenção dos esforços dos líderes e demais colaboradores da empresa.

Os valores são as crenças básicas de uma organização. E de forma simples deve responder o que é importante para a empresa.

2. Análise externa: aborda as atividades de identificação dos elementos estratégicos associados ao contexto externo no qual a organização está inserida.

O objetivo dessa análise é identificar: as questões relevantes e variáveis de decisão relacionadas ao ambiente externo; e as oportunidades, os riscos ou ameaças, e as restrições (legais, sociais, ambientais entre outras).

3. Análise interna: considera as atividades que identificam as questões estratégicas relacionadas aos aspectos internos de uma organização.

O objetivo dessa análise é identificar: as questões relevantes e variáveis de decisão relacionadas ao ambiente interno da organização; os pontos fortes e os pontos fracos (vulnerabilidades). Para isso são analisados: recursos tangíveis e intangíveis da organização, processos e atividades, produtos e serviços oferecidos pela empresa, a governa corporativa, e o contexto organizacional que se refere a estrutura organizacional, a cultura e a estrutura de poder.

4. Escopo de atuação: aborda as decisões acerca de quatro questões estratégicas: setor de atuação; definição de clientes e usuários, atuais e futuros; região de atuação; linha de produtos e serviços.

A primeira é o setor de atuação que se refere a quais os seguimentos e atividades eu a empresa atua ou deseja atuar. 
A segunda questão é a definição de clientes e usuários. Ou seja, quem a empresa atende hoje e quem deseja atender no futuro.

A terceira é referente a definição de quais as regiões de atuação da empresa hoje e no futuro.

A quarta questão trata da definição dos produtos e serviços que a empresa oferece hoje e pretende oferecer no futuro.

5. Posicionamento estratégico: engloba dois conjuntos de decisões: posicionamento estratégico e a proposta de valor.

O primeiro conjunto define a posição que a organização e as suas marcas, produtos e serviços ocupam, ou desejam ocupar, no mercado em relação a concorrência.

O segundo é referente a proposta de valor da empresa, ou seja, o conjunto de benefícios entregues ao cliente por meio dos produtos e serviços da organização, considerando o patamar de preço. Para essas definições são analisados os seguintes pontos: quais problemas dos clientes serão resolvidos? Quais os benefícios do produto ou serviço oferecido? Como esses produtos ou serviços resolveram o problema do cliente? Quais os diferencias da organização? O que ela faz diferente ou melhor que a concorrência?

6. Modelo de negócios: define a forma como a organização deve ser estruturada com o objetivo de criar, entregar e capturar valor.

O uso dos preceitos da modelagem de negócios tem como objetivos: projetar uma organização de forma coerente e integrada; identificar os elementos da organização que devem ser alterados ou desenvolvidos para aterem as decisões estratégicas; identificar se algum elemento pode contribuir para redefinir a estratégia da organização.

7. Iniciativas estratégicas: afim de identificar e selecionar as iniciativas e projetos estratégicos que atendem a estratégia formulada.

As iniciativas estratégicas fornecem os elementos concretos para que a empresa de fato execute a estratégia definida. 
8. Monitoramento e aprendizado: contempla o monitoramento externo, interno e o aprendizado estratégico adquirido.

O monitoramento externo consiste na identificação e análise de informações externas que podem impactar a organização. O monitoramento interno é o acompanhamento das atividades de execução da estratégia através de indicadores de desempenho, além de implantar e acompanhar a execução de projetos estratégicos.

$\mathrm{O}$ aprendizado estratégico se refere a incorporação de experimentações controladas e de lições aprendidas no processo de gestão estratégica. Sendo esse um fator importante para lidar com as incertezas inerentes a tomada de decisões estratégicas.

Importante ressaltar que o a gestão estratégica é um processo dinâmico, contínuo e adaptativo, é um processo de aprendizado contínuo que contribui para a resiliência da organização. 


\section{APRESENTAÇÃO DO CASO}

A empresa a ser estudada na presente pesquisa é a Ciao Mao, marca paulistana de calçados fundada em 2007 pela designer Priscila Callegari. O projeto diferenciado viabilizou a existência da empresa em um cenário altamente competitivo e dominado por grandes players como grupo Arezzo (detentores das marcas Arezzo, Schutz, Ana Capri, Fiever e Alexandre Birman), grupo Priority (das marcas West Coast e Cravo e Canela), grupo Paquetá (das marcas Capodarte e Dummond), grupo Carmen Steffens, grupo Picadilly, entre outros. A sua relevância só foi atingida devido às decisões estratégicas tomadas pela sua líder em todas as esferas: desenvolvimento de produto, apresentação no varejo, gestão de pessoas e relacionamento com fornecedores.

Esses diferenciais possibilitaram reconhecimento nacional e internacional, conquistando as seguintes premiações de design: IDEA/BRASIL 2008 (ouro), IDEA 2008 (bronze), TOP XXI 2009 (1\%lugar), BRAZIL DESIGN AWARD e em 2013 o Prêmio Direções da ABICALÇADOS (Associação Brasileira de Calçados) na categoria Design e em 2017 na categoria Internacionalização. A marca também esteve presente na exposição MAM (Museu de Arte Moderna de São Paulo) "Design Brasileiro Hoje: Fronteiras", no SPFW (em parceria com a estilista Fernanda Yamamoto), na Bienal Brasileira do Design 2010 (Curitiba) tendo como tema a sustentabilidade, na Bienal Brasileira de Design 2012 (Belo Horizonte), na Bienal Brasileira de Design 2015 (Florianópolis), na Bienal Iberoamericana de Design (Madri-Espanha), além de ter exposto seus produtos nas Design Weeks de Milão e Nova York. Como destaque em empreendedorismo, a empresa foi selecionada como uma das "99 Soluções Inovadoras" do SEBRAE em 2009 e como um dos 20 destaques do Brasil em uma publicação da consultoria KPMG, junto com empresas como: Cacau Show, Wizard, Bio Ritmo, CVC, Buscapé, Habib’s, entre outras. 


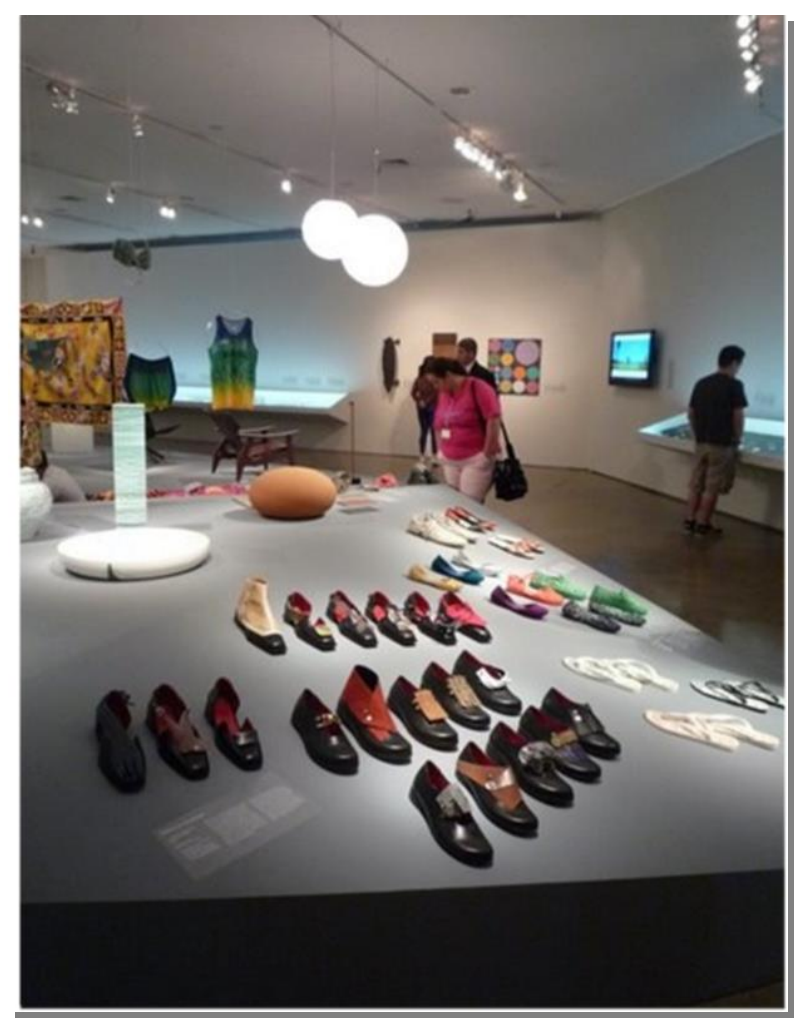

Figura 4 - Ciao Mao na exposição Design Brasileiro Fronteiras no MAM-SP FONTE: Material de divulgação da empresa Ciao Mao

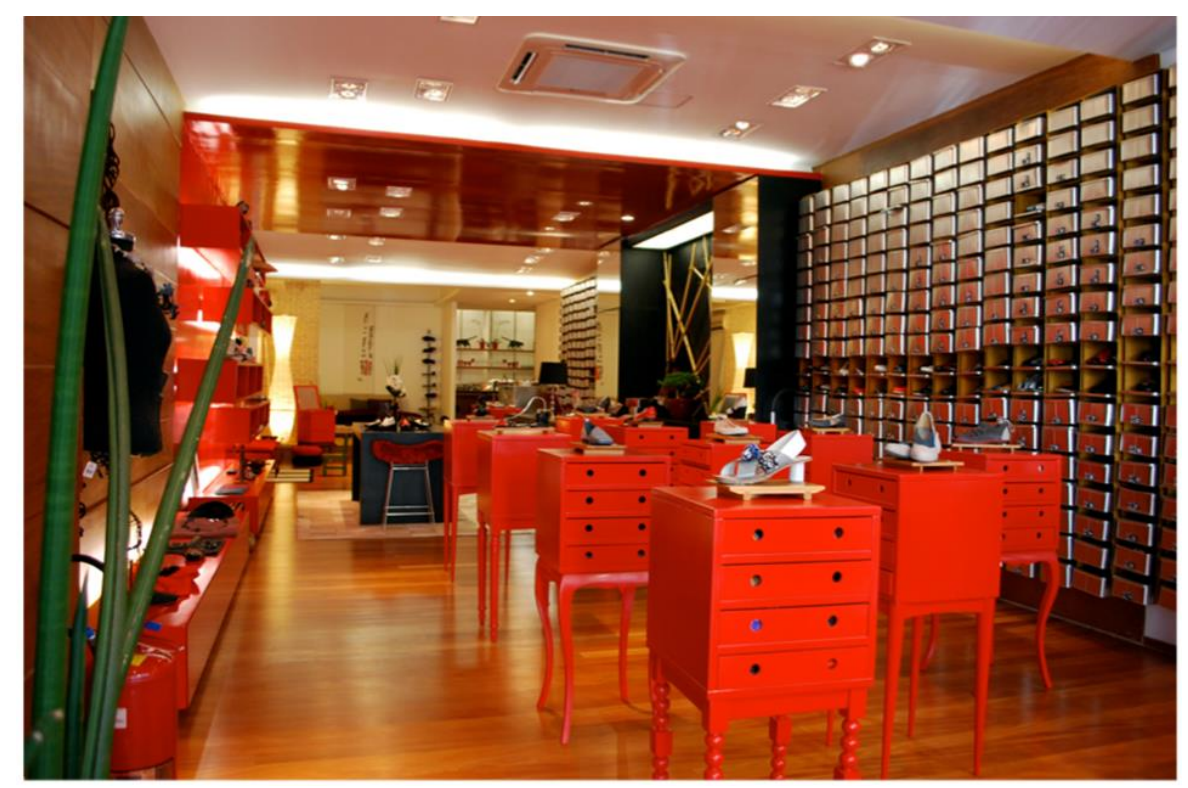

Figura 5 - Loja Ciao Mao em São Paulo

FONTE: Material de divulgação da empresa Ciao Mao

Atualmente, a Ciao Mao atende os mercados feminino, masculino e infantil; possui três lojas próprias em São Paulo, uma loja de rua no bairro de Pinheiros, uma loja no Shopping Pátio 
Higienópolis e a terceira no Shopping Market Place, do grupo Iguatemi. Desde 2016, iniciou sua expansão internacional, abrindo mercado em outros sete países: EUA, França, Itália, Inglaterra, Portugal, Líbano e África do Sul.

A empresa apresenta alta performance se comparada a empresas concorrentes. Por questão de sigilo a empresa não divulga dados financeiros recentes de operação, mas temos conhecimento que a Ciao Mao teve um pico de crescimento de $78 \%$ no faturamento de 2012 em relação a 2011. Nas comparações SSS (same store sales, ou seja, vendas nas mesmas lojas, métrica utilizado no varejo) do primeiro semestre de 2013, a empresa teve um crescimento médio de 30\%, enquanto empresas de grande porte como Arezzo, principal player deste mercado, divulgaram crescimento de apenas $1,2 \%$ no mesmo período (Valor Econômico, 2013).

A marca Ciao Mao se mostra relevante, pois se destacou em um mercado altamente competitivo. A empresa propôs um produto inovador ao mercado, sendo necessária uma estratégia de como produzi-lo e comercializá-lo. Nos anos seguintes à sua abertura, a empresa continuou um processo contínuo de adequação de seus processos produtivos, administrativos e comerciais. Com uma liderança focada, mas ao mesmo tempo disposta a achar soluções criativas para seus desafios.

Um dos principais diferenciais criados pela empreendedora e que será abordado com mais profundidade neste trabalho, é a criação do conceito de sapatos interativos, em que uma base de sapato pode ser combinada com diversos acessórios, multiplicando sua aparência e funcionalidade.

O conceito de sapatos interativos não foi mera inspiração de uma mente criativa, ou uma imposição estética da cultura da moda. Foi sim o resultado de um questionamento profundo dos paradigmas da indústria calçadista. A solução encontrada pela empreendedora buscou atender as necessidades de várias partes envolvidas concomitantemente. 


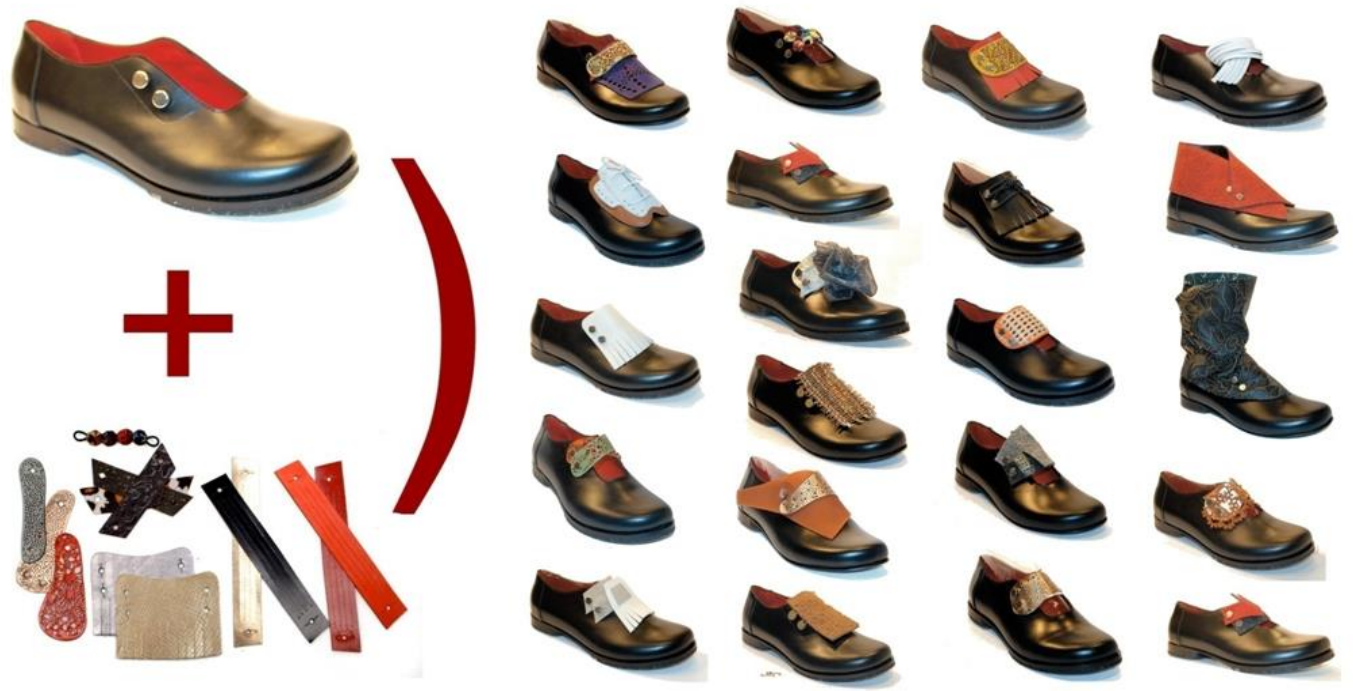

Figura 6 - Conceito de Sapatos Interativos

FONTE: Material de divulgação da empresa Ciao Mao

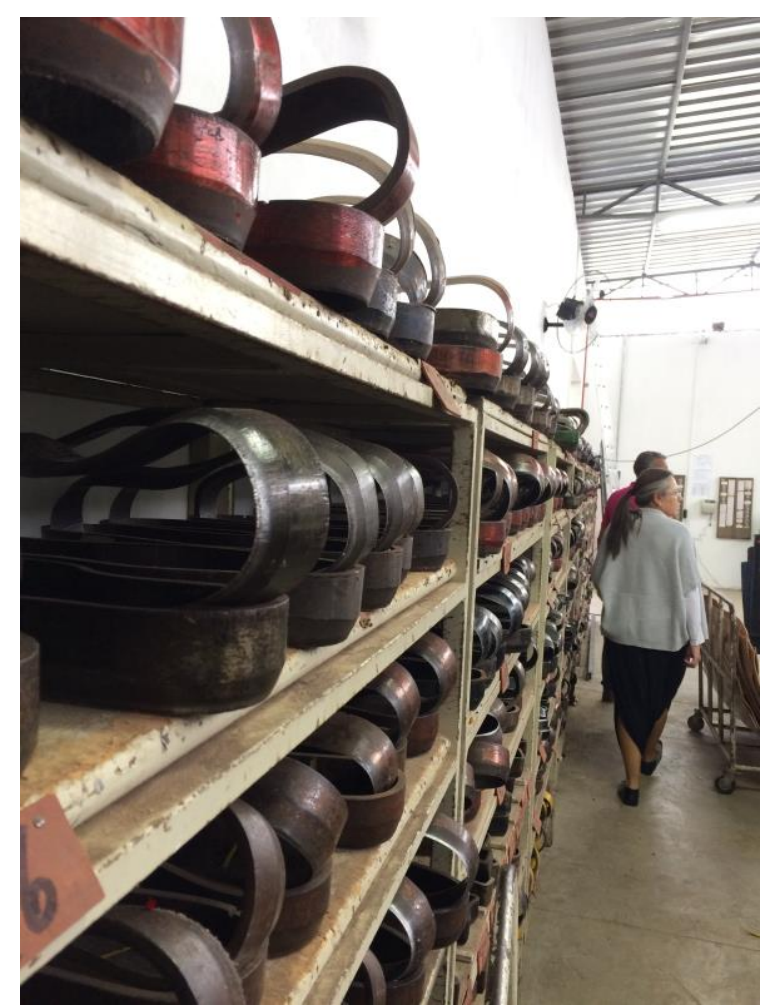

Figura 7 - Priscila visita uma das fábricas de solados

FONTE: Autor 
Do ponto de vista do fabricante de sapatos, ele tem que desenvolver um menor número de formas, matrizes, facas e componentes do sapato, reduzindo investimentos. Em uma coleção normal de calçados, há a necessidade de se desenvolver muitas variações de modelos, alterando fivelas, cores, decotes, canos etc. Essa otimização de modelos, facilita a produção e reduz investimentos.

Do ponto de vista do fabricante de acessórios, a Ciao Mao capacita pequenos produtores locais. Um exemplo é de uma profissional que havia saído da indústria de calçados e buscava uma nova fonte de renda. Atualmente, esta profissional se tornou uma confiável fornecedora da empresa, montou uma micro-empresa e faz produções de milhares de peças por mês com uma alta rentabilidade. Esse acessório era um conceito de produtos inexistentes no mercado. Não era mero ornamento sobre os calçados: ele era um componente de fato, que deve ter modelagem adequada para um bom calce. A produção destes acessórios não se encaixava nem em um fabricante de calçado nem em uma confecção de vestuário. $\mathrm{O}$ uso desses pequenos arranjos produtivos é uma solução para ambas as partes e vai ao encontro de um dos desejos iniciais da empreendedora que era valorizar o trabalho manual do artesanato brasileiro, gerando renda e trabalho.

Do ponto de vista do cliente, ele pode adquirir um sapato de alta qualidade, que respeitam princípios de ergonomia, que usa materiais adequados, que tem uma responsabilidade sócioambiental em todo seu processo de fabricação, ainda assim atendendo seus anseios por um produto de moda. Com $10 \%$ do valor de um calçado, ele consegue comprar um par de acessórios que dará uma nova "cara" e utilidade para o sapato. Um dos acessórios, por exemplo, é um cano de bota, que permite que o cliente tenha uma bota para os dias mais frios, porém como no Brasil o clima de inverno é curto, ela pode rapidamente renovar o calçado para um modelo mais adequado para o calor. O produto respeita a diversidade $\mathrm{e}$ individualidade das pessoas, sendo refletida no lema da marca: "Múltiplo e singular como você”. 


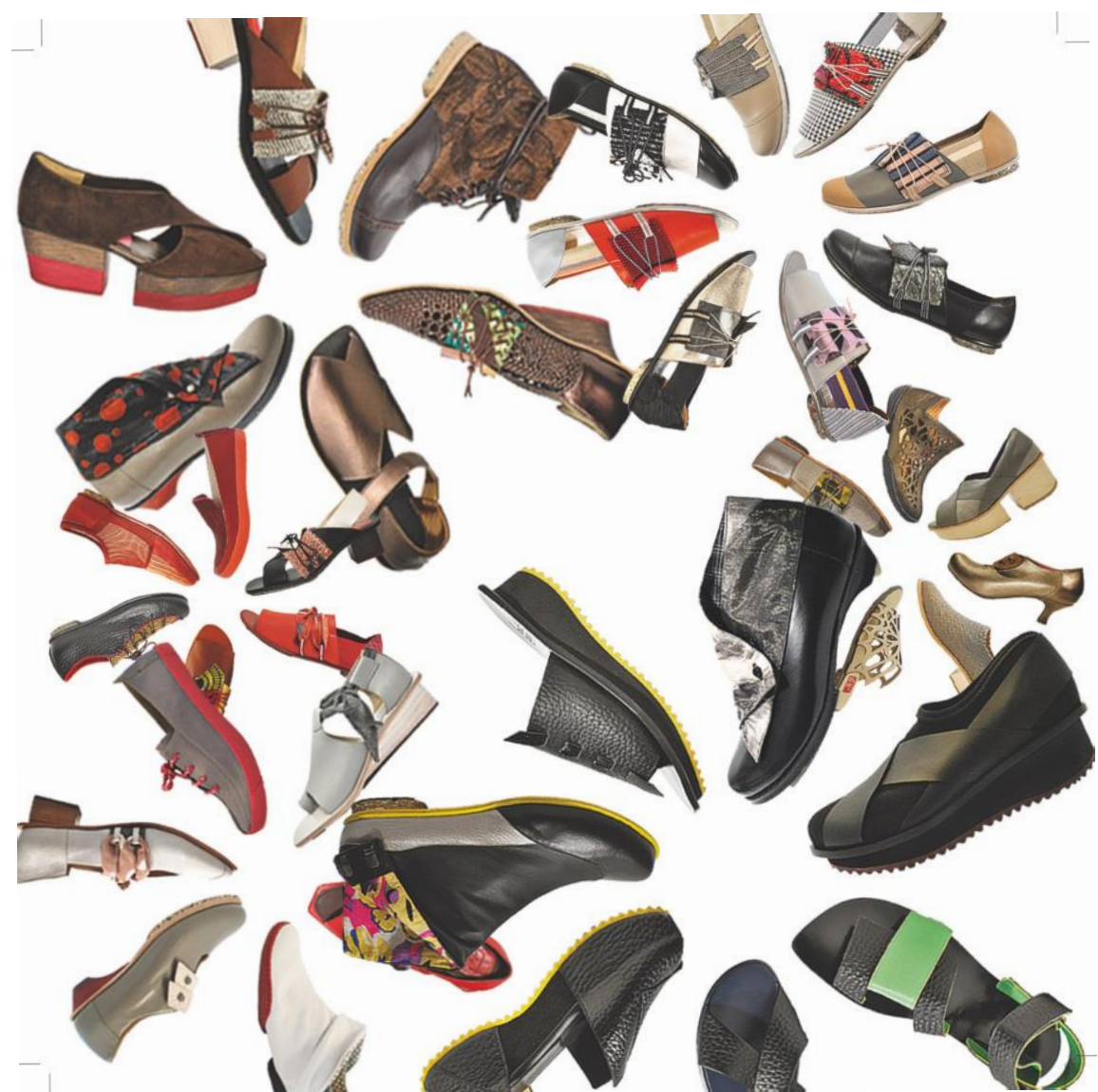

Figura 8 - Diversos modelos de calçados da Ciao Mao

FONTE: Material de divulgação da empresa Ciao Mao 


\section{ANÁLISE DE DADOS}

\subsection{Introdução}

As empresas tomam decisões diárias em diversos níveis: operacionais, táticos e estratégicos. Porém não temos a intenção neste estudo em entender os processos de decisões corriqueiras, de nível operacional ou mesmo tático, mas sim os estratégicos, aqueles que definem os direcionamentos da empresa e causam impactos de longo prazo nos resultados.

Quando tratamos de uma empresa nascente de pequeno porte, como a Ciao Mao, o papel do decisor de nível estratégico está centrado em um indivíduo, a empreendedora.

A empresa em questão foi fundada pela designer Priscila Callegari e irá completar 10 anos de fundação em novembro de 2017. Neste estudo abordaremos as decisões estratégicas tomadas pela empreendedora entre 2005 a 2007, período em que a designer estava pesquisando, planejando e definindo as diretrizes para a constituição de sua nova empresa.

Para a elaboração deste trabalho primeiramente foi realizada uma análise da empresa baseado na teoria administrativa e em fontes de dados secundários como relatórios da empresa, matérias e entrevistas com a empreendedora publicadas em livros, revistas e jornais, assim como outros trabalhos acadêmicos que citaram o caso da empresa Ciao Mao.

Na sequência, foi preparada uma entrevista semi-estruturada com a empreendedora (Apêndice 1). O objetivo da entrevista foi compreender como se deu o processo decisório nas diversas etapas da criação da empresa. A tese de livre docência do Prof. Marcelo Pedroso Caldeira de 2016 foi utilizada como uma linha condutora para este estudo, focando na descrição do processo de formação de estratégia das empresas. O autor definiu em seu trabalho uma sequência de 8 etapas nas quais as principais decisões estratégicas são tomadas.

Para a definição do roteiro da entrevista, primeiro foi feito um amplo estudo da empresa através de dados secundários. Nesta trajetória percebeu-se que o processo de criação da estratégia da Ciao Mao não seguiu uma cronologia sequencial das etapas propostas no trabalho de Cardoso (2016). Havia evidências que todas as etapas foram contempladas na criação da empresa, mas estas não seguiam uma sucessão linear, elas se entrelaçavam, complementando e influenciando umas às outras. Por exemplo, as questões de Análise Externas - etapa 3 - são fundamentais para a definição da etapa 1 de Intenção Estratégica, assim como ambas foram necessárias para as decisões tomadas na etapa 4. 
Identificou-se também que antes das oito etapas de formação da estratégia da Ciao Mao, houve uma importante decisão na trajetória da empreendedora: o fechamento da sua antiga empresa e a transição para a abertura da nova.

Considerando estas informações sobre o caso, o autor realizou a entrevista com Priscila Callegari. Após a realização da mesma, deu-se início a análise de dados buscando pontos de convergência e divergências entre as teorias de administração estudadas e o caso prático. No final de cada etapa foram destacadas as principais lições aprendidas no processo analisado.

\subsection{A antiga empresa}

Antes de decidir pela abertura da empresa Ciao Mao, Priscila possuía uma outra empresa, a Quadro Design, que prestava serviço de design gráfico, arquitetura promocional, visual merchandising e identidade de marca para grandes empresas como Hering, Kopenhagen, Marie Claire, PUC e Umbro. O fechamento desta empresa foi o momento de ruptura que deu início à pesquisa para a abertura do novo empreendimento. Assim sendo, entende-se que esta foi a decisão estratégica inicial de todo o processo. Por que fechar a antiga empresa e abrir uma nova em outra área?

\section{DECISÃO: AMPLIAR A EMPRESA EXISTENTE}

Priscila relata, na entrevista concedida, que anos antes de pensar em abrir a Ciao Mao, o seu desejo era que a Quadro Design crescesse. A empresária chegou a tomar ações efetivas para essa ampliação: mudou de escritório e contratou mais funcionários.

A ideia naquele momento era que aquele se tornasse um negócio muito maior e que não fosse tão dependente dela. Porém a empresária viu esse movimento como falho. Apesar de ter tido sucesso na expansão do negócio, aumentando o número de clientes e de receita, o trabalho continuava muito vinculado a suas competências individuais, era difícil que outro profissional de sua equipe assumisse os projetos. Segundo ela relata, toda vez que delegava o trabalho para um membro de sua equipe, o próprio cliente exigia novamente a sua presença. $\mathrm{O}$ modelo de negócio não funcionou, a premissa de que o trabalho era replicável era falha, e por mais 
que houvesse crescimento da empresa, isso sobrecarregou a empresária, o que tornava o crescimento insustentável.

Em uma análise da própria designer, ela conclui que o tipo de serviço era de fato difícil de ser replicável, o serviço prestado exigia um olhar multidisciplinar, sendo um perfil muito específico de profissional, não encontrado facilmente no mercado. Por envolver características artísticas e técnicas, o cliente queria o trabalho autoral da designer e não a simples execução de um projeto.

\section{Lição aprendida:}

- Não adianta insistir em uma estratégia que não está dando certo só porque ela já foi iniciada. Mesmo havendo resultados de curto prazo, é necessário avaliar a sustentabilidade do modelo de negócio. Nesse caso, o objetivo de Priscila não era apenas crescimento de faturamento, mas também um negócio que fosse menos dependente dela.

\section{DECISÃO: FECHAR A ANTIGA EMPRESA E ABRIR UMA NOVA}

$\mathrm{Na}$ entrevista, a designer relata que uma das motivações para iniciar uma nova empresa, era a possibilidade de fazer um projeto por completo. Ela vivenciava uma grande frustração na sua empresa anterior: os projetos entregues aos clientes eram na maioria das vezes deturpados, independente do grande trabalho empregado em cada um deles.

Os clientes encomendavam os projetos, mas no fim os alteravam, seja por questão de verba, por questão de um briefing passado incorretamente ou porque o cliente não entendia profundamente a proposta feita. A sensação da designer era que todos os seus projetos envolviam uma grande dedicação de sua parte que não era aproveitada em todo seu potencial pelo cliente. Um dos grandes problemas como modelo de negócio era que este tempo e esforço dedicado à fase de elaboração do projeto não era devidamente remunerado. Um exemplo que ela cita é a elaboração de um trabalho de apostila sobre visual merchandising para uma grande empresa. Foi realizado um trabalho extenso, envolvendo inclusive literaturas técnicas estrangeiras que foram traduzidas especificamente para este projeto. Porém ao projeto ser entregue para o cliente, o feedback foi de que a apostila era muito grossa e que 
independente da qualidade do conteúdo, o cliente decidiu que não despenderia gastos com a impressão. O trabalho foi assim desperdiçado em seu potencial.

Ao avaliar a cadeia de valor deste negócio - venda de serviço de design para empresas de varejo - Priscila identificou que haviam dois pontos cruciais que impediam sua empresa de crescer: dificuldade de formar uma equipe autossuficiente e a pouca valorização do seu trabalho pelo cliente.

A motivação inicial para a abertura do novo negócio era então, fazer por completo um projeto que ela acreditava. Como a própria designer coloca: "de uma frustração buscou-se uma solução".

\section{Lições aprendidas:}

- O valor que o profissional acredita que seu trabalho tem deve estar em sintonia com o valor percebido pelo cliente. Uma discrepância nesses valores traz frustração ao profissional e insustentabilidade do negócio no longo prazo.

- O empresário deve repensar seu negócio quando percebe que não está recebendo os resultados esperados, não apenas financeiros, mas também caso a realização dessa atividade não estiver mais em sintonia com seus objetivos de vida. Percebe-se, neste caso, que para a empreendedora era importante ter uma realização profissional que fosse além do dinheiro. $\mathrm{O}$ excesso de dependência da empresa em seu trabalho e a falta de autonomia nas decisões finais de cada projeto era frustrante.

\subsection{Escopo de Atuação}

No subcapítulo anterior, pode-se identificar que a designer realizou uma das importantes etapas defendidas pela teoria administrativa, ela realizou a exploração de alternativas antes da tomada de decisão. A alternativa era ampliar a empresa existente e replicar sua atuação com uma equipe treinada. Essa estratégia foi implementada e testada, porém se mostrou ineficiente, necessitando que a empreendedora aprendesse com este caso e reavaliasse as alternativas. Partiu-se então para a criação de uma nova empresa. 
Conforme descrito no início deste capítulo, as etapas não seguiram uma ordem cronológica. Para este trabalho foi optado por inverter a etapa 1 pela etapa 4, definidas por Pedroso (2016), por desencadearem um raciocínio mais coerente de acordo com descrição da história relatada pela entrevistada.

Esta etapa está relacionada às decisões estratégias realizadas pela empresa como: qual o setor de atuação da organização? Em quais segmentos pretende atuar? A quem se deseja atender? Qual a sua região de atuação? Quais os produtos e serviços que serão oferecidos?

\section{DECISÃO: DEFINIR O SETOR DE ATUAÇÃO DA EMPRESA - CALÇADOS}

A Quadro Design atendia muitos clientes do varejo, em especial de moda, possibilitando que a designer adquirisse grande conhecimento na área e uma rede de contatos no setor. Através desta experiência a empresária identificou que existiam brechas de oportunidades no mercado brasileiro. Porém neste momento, ainda não estava afunilando sua escolha para o mercado calçadista.

Inicialmente uma das alternativas pensadas para o negócio era a de uma loja multifuncional atuando no varejo com peças especiais e foco no trabalho de curadoria, ou seja, tendo uma seleção minuciosa do mix de produtos. Existem modelos de negócios similares pelo mundo, como são os casos das lojas Collete e Merci em Paris, que revendem produtos de moda, artigos para casa, papelaria, mobiliário, livros e perfumes, e são conhecidos pela sua identidade visual e curadoria de marcas e produtos. A intenção nestes negócios é que o cliente se identifique com a seleção realizada pela loja e que essa represente o seu estilo de vida. Há outros exemplos bem-sucedidos como a Dover Street Market de Londres e a 10 Corso Como que tem filiais em Milão, Seul, Xangai, Pequim e Nova Iorque.

Durante o desenvolvimento desta primeira ideia de negócio, Priscila fez uma análise de suas capacidades profissionais e pensou em como utilizá-las como diferencial. Imaginava que a loja se beneficiaria da sua expertise em visual merchandising, arquitetura promocional e seu amplo conhecimento do mercado de moda e design. Pensando nas teorias de administração, pode-se entender que ela realizou uma avaliação dos aspectos internos, ou seja, seus pontos fortes e fraquezas, como descreveria Porter (1980). No caso de uma pequena empresa 
nascente as características da organização se entrelaçam com as características pessoais do próprio empreendedor.

Durante este processo de pesquisa, a empresária afirmou que já documentava todas as informações encontradas sobre o tema, sejam elas através de anotações pessoais, seleção de fotos, artigos, referências ou seleção de possíveis fornecedores. Percebe-se que mesmo com o leque de possibilidades ainda aberto, a profissional tinha um pensamento racional e organizava o conhecimento adquirido e insights de forma ordenada. Há então um indício de que seu processo criativo para a tomada da decisão não é meramente intuitivo, e sim baseado em intensa coleta e análise de dados.

Dentro desse projeto de loja multifuncional já estava contemplado atuar com calçados, mas neste momento, ainda não era a construção de uma marca ou criação de modelos com design original, mas sim a seleção de produtos de outras marcas para revenda.

A constituição da loja multifuncional envolvia dois sócios: um cliente de longa data da empresa anterior e uma ex-sócia da Priscila. Porém no decorrer do processo de planejamento, Priscila buscou conhecer melhor estes dois indivíduos e descobriu que não poderia avançar nesta sociedade, por haver divergências em questões financeiras e de ideais.

Essa conjuntura interrompeu a fundação deste projeto de loja. Porém a ampla pesquisa realizada pela Priscila, mostrava que havia boas oportunidades em outras áreas, especialmente naquela que mais lhe atraía: o calçado. Esta atração, não era apenas por gostar deste produto, mas quanto mais a designer estudava sobre o tema, mais via um nicho de mercado a ser explorado. Vislumbrou então uma oportunidade de utilizar suas expertises, trabalhar com o que gostava: desenvolvimento de produto e criação de marca, além de ter um negócio com grande potencial de sucesso.

Quando questionada porque decidiu delimitar a área de atuação da empresa trabalhando apenas com calçados e não com bolsas ou demais produtos correlatos, a empreendedora é bem enfática em afirmar que precisava focar pois este já era um universo muito amplo e complexo, para alguém que não vinha da área, e que para realizar bem o projeto ela precisava entender com profundidade o assunto. Ela afirma que sabia que, ao buscar inovar nesta área, ela iria cometer erros, e que esses erros eram esperados e parte do processo de aprendizagem, 
porém para minimizar essas perdas a alternativa era delimitar a diversidade de produtos e focar nos sapatos, e inicialmente apenas os femininos.

Ao analisar esse relato, pode-se notar que a empresária deu grande importância para uma das principais etapas da teoria de tomada de decisão racional, chamada de exame da situação por Stoner e Freeman (1992), etapa em que ocorre: a definição do problema, a identificação dos objetivos da decisão e o diagnóstico da causa. Essa etapa se assemelha a proposta de Simon (1965), que é chamada de etapa de inteligência ou investigação, momento em que é explorado o ambiente onde os dados são trabalhados em busca de problemas e oportunidades. Priscila estudou amplamente múltiplos cenários e identificou problemas e oportunidades nesta proposta de novo negócio. Ela também teve a flexibilidade para mudar sua estratégia ao se deparar com novas informações que comprometiam o plano original.

\section{Lições aprendidas:}

- Antes de definir qual o escopo de atuação, é importante estudar o mercado, buscar benchmarks e avaliar o cenário em que se está inserindo. Um modelo de negócio pode funcionar bem em um país e pode não ser replicável em outra realidade. Priscila identificou um modelo de negócio bem-sucedido de lojas multifuncionais de luxo em outros países, mas teve a cautela de estudar o mercado nacional, não só a demanda, como também a existência de fornecedores e formato de operação do negócio.

- No momento de pesquisa para escolha de escopo de atuação é importante que o empreendedor esteja aberto às oportunidades, ele não precisa fechar o foco. No momento da ideação é importante não perder o senso do possível. Se Priscila estivesse excessivamente focada na sua primeira ideia de negócio era possível que nunca tivesse enxergado a oportunidade de criar uma marca de calçados.

- Outro comportamento importante que pode ser identificado no caso, é o autoconhecimento do empreendedor. Quando o principal tomador de decisões avalia características e objetivos pessoais de forma crítica antes da criação de uma nova empresa, esta tem mais chance de se beneficiar dos pontos fortes e mitigar os riscos dos pontos fracos.

- É benéfico que todo trabalho de pesquisa seja documentado de forma ordenada, mesmo que o escopo final e atuação se altere, os conhecimentos agregados podem 
gerar insights importantes. Priscila estudou um mercado de loja multifuncional e no processo identificou a oportunidade na área de calçados.

- O empreendedor deve avaliar com cuidado a formação de uma sociedade, pois será com estes indivíduos que se dividirá a responsabilidade das tomadas de decisão. A inexistência de afinidade pode causar atritos na operação da empresa e o eventualmente seu insucesso. No caso da Priscila, ela teve a prudência de conhecer profundamente seus possíveis sócios antes de tomar a decisão de se vincular a eles, assim como teve a coragem de dar um passo para trás e redirecionar o caminho da sua empreitada a partir do momento que identificou uma divergência de valores.

- Um empreendedor com recursos e tempos escassos precisa ter foco para dominar um assunto, já que normalmente todo o trabalho inicial da empresa está concentrado neste único indivíduo. A designer afirma a importância de entender a fundo o mercado em que se deseja atuar. Através do entendimento da cadeia de valor do produto ou serviço pode se identificar as necessidades não atendidas ou mal atendidas, sendo estas oportunidades para empresa atuar.

\section{DECISÃO: FOCAR NO PÚBLICO FEMININO PARA CALÇADOS EM SÃO PAULO}

Priscila descreve que teve um insight de forma informal sobre o possível público alvo. A designer, mesmo antes de trabalhar na área, sempre buscava sapatos diferentes dos normalmente utilizados. A empresária tinha um "olhar" - como ela mesmo define - para achar peças interessantes. Normalmente adquiridos no exterior, esses produtos atraiam a atenção das pessoas com quem cruzava, sejam amigas ou clientes, que questionavam onde ela havia adquirido aqueles produtos, e que relatavam a ela que tinham desejo por sapatos diferentes e de boa qualidade, mas nunca os achavam no Brasil. Priscila não tinha plena consciência naquele momento, mas estava iniciando ali a identificação de suas primeiras clientes.

Através de suas pesquisas, a designer concluiu que o consumo de calçados feminino era muito maior do que o de masculinos e infantil. Pelas observações da empreendedora, se tratava de um público carente em produtos inovadores e de design original. Havia uma enorme oferta de calçados, mas sempre com estilos padronizados. Ela via também uma demanda por produtos que aliassem conforto sem perder a beleza, não se categorizando como calçados ortopédicos. 
Identificou também a questão da interatividade e personalização como um importante diferencial, visto como uma tendência de mercado por possibilitar a participação criativa da cliente. Imaginou então um público final eclético em profissões ou faixas etárias, mas que convergisse no desejo de um produto que atendesse plenamente sua função, o caminhar confortável, e que agregasse um fator de arte e design admirado por este público.

Ela considerou também um fator prático de redução de custos e encurtamento de tempo de desenvolvimento. $\mathrm{O}$ fato de trabalhar com calçados femininos permitia que ela mesmo testasse as peças pilotos, questão fundamental tratando-se de um produto inovador, não só na estética, mas na sua construção. A designer queria testar adequadamente o produto, pois acreditava que um calçado primeiramente tem que atender bem sua função, o de caminhar com conforto. Além disso, ela havia observado, muitos fabricantes não valorizavam esse quesito, as criações desses concorrentes derivavam de cópias de outras marcas, ou eram criadas atendendo a estética, mas não a ergonomia. Priscila sempre acreditou que o design de um calçado é um projeto complexo que deveria atender diversas necessidades. Segundo trecho de um relato da designer descrito no trabalho de Hayashi e Ramos (2013, p.5):

\footnotetext{
Como designer sempre tive especial interesse por desenho de sapatos e sempre acreditei que os sapatos, por envolverem um meio de transporte, os pés, deveriam ser considerados mais do que meros acessórios de moda.

A função (proteção/ conforto) muitas vezes é relegada a segundo plano pela forma imposta pela moda/cultura. O bem-estar tanto no sentido de "sentir-se bem" como no de "estar bem" deveria ser atendido por completo. Entendo que os sapatos dizem muito sobre uma pessoa. Neles, diferente das roupas, ficam "marcadas" as pisadas individuais. Como consumidora não me sentia satisfeita. Idealizava sapatos que não conseguia encontrar. Quando viajava para a Europa ou Estados Unidos, me encantava com a diversidade de modelos oferecidos, com a riqueza de possibilidades com o design e a inovação.
}

Em relação a atuação geográfica, a empresária iniciou focada na cidade de São Paulo. Conforme o relato publicado na revista da ABICALÇADOS (2013), a Ciao Mao tinha o pensamento de design como linha condutora, o projeto não se limita à criação do produto, ele engloba também a sua apresentação e venda ao consumidor final. A empresa criou uma proposta de varejo própria para atender à necessidade do consumidor contemporâneo que busca experiências multissensoriais. Ou seja, o consumidor deveria poder vivenciar, interagir e influenciar o ato da compra. Assim sendo, os produtos até hoje têm como foco a oferta em lojas varejistas monomarcas, onde a empresa detém o controle do mix de produtos, treinamento de equipe de venda, arquitetura de loja e operação e pós-vendas. 
Porém o crescimento e operação com lojas monomarcas próprias exige investimento inicial alto (compra de ponto comercial, reforma de loja, mobiliário, contratação e treinamento de equipe) e necessita de supervisão direta, assim sendo, a empresa concentrou sua atuação na cidade de São Paulo para que os gestores pudessem acompanhar de perto as operações. Iniciou em 2007 com uma loja na região de Pinheiros em um imóvel próprio da empreendedora, em 2008 abriu uma segunda loja no bairro do Jardins, e a expansão seguiu com mais duas lojas em shoppings centers da cidade: Shopping Pátio Higienópolis em 2011 e Shopping Market Place em 2013.

A marca vendeu seus sapatos em parceiros lojistas multimarcas em diversas cidades brasileiras, mas esse canal de venda nunca ultrapassando $10 \%$ do faturamento da empresa. Em 2016, iniciou uma operação de $e$-commerce e um bem-sucedido projeto internacional. Em 2017, com menos de um ano de operação internacional, a marca passou a ser comercializada em mais de 7 países e conquistou o prêmio Direções da Associação Brasileira da Indústria de Calçados na categoria de Internacionalização de marca.

\section{Lições aprendidas:}

- Um empreendedor deve estar atento as informações ao seu redor. Podem haver indícios de uma oportunidade de negócio em situações inesperadas. No caso de Priscila, observar os comentários de pessoas em seu redor a respeito de seus sapatos deram o insight de um nicho de mercado a ser explorado. Porém é essencial que um profissional competente não se paute apenas por insights, uma pesquisa aprofundada deve corroborar para a definição desta oportunidade de negócio.

- Quando definido o campo de atuação, é importante que um produto não atenda uma necessidade única, ele sempre tem diversos ângulos a serem analisados. No caso dos sapatos, é um produto que deve atender inúmeras necessidades que vão de aspectos tangíveis como conforto e proteção até questões intangíveis como status e satisfação pessoal. Um empreendedor deve estar atento a saciar estar diversas necessidades concomitantemente.

- Identifica-se também no relato a importância de que a atuação da empresa esteja alinhada com os ideais e objetivos pessoais do empreendedor. Uma empresa deste perfil também tem como objetivo cumprir uma satisfação pessoal deste indivíduo. No 
caso da Priscila, seu gosto por moda, design e em especial trabalhar com o produto calçado.

- A região de atuação de uma empresa não pode ser definida pensando apenas em aspectos mercadológicos, deve se considerar questões de viabilidade de operação. Tendo um olhar estrito de onde haveria o público mais adequado para a Ciao Mao, rapidamente poderíamos apontar os polos de varejo de luxo da cidade de São Paulo como a Rua Oscar Freire ou o Shopping Iguatemi. Porém, tratando-se de um empreendimento com recursos limitados, é importante que se avalie alternativas que otimizem os recursos existentes para o empreendedor. No caso da Ciao Mao, Priscila possuía um imóvel onde operava sua empresa anterior em uma localização da cidade que permitia a abertura de um comércio, conforme avaliado no zoneamento local na prefeitura, assim como era uma região que tinha potencial de atração de clientes. $\mathrm{Ou}$ seja, à primeira vista podia não parecer o local ideal, mas era uma alternativa que harmonizava o potencial de vendas com os recursos disponíveis.

\subsection{Análise Externa}

Segundo Pedroso (2016), esta etapa aborda as atividades de identificação dos elementos estratégicos associados ao contexto externo no qual a organização está inserida, considerando oportunidades, riscos e limitações.

Entendendo que a decisão principal do modelo proposto por Pedroso é a definição da estratégia da empresa, e fazendo um paralelo com a teoria de tomada de decisão, esta etapa pode ser apontada como a de inteligência e investigação de Simon (1965) ou a de exame da situação de Stoner e Freeman (1992).

Em entrevista, a empreendedora afirma a importância de abrir o leque de opções na hora da pesquisa. Para ela, neste momento, devem se manter abertas todas as possibilidades, não focando no resultado do produto final. As origens dos conhecimentos que fundamentarão a escolha da melhor alternativa devem proceder e convergir de diversas áreas, sejam elas econômica, social, semiótica ou de moda. 
As soluções para uma empresa não vêm prontas, segundo as palavras da designer: "as respostas vão aparecendo, elas vão fluindo ". Ela ainda defende que a resposta certa acaba se repetindo nos vários olhares, ou seja, respondem perguntas diferentes.

A empreendedora explica que na sua formação de designer, aprendeu que o primeiro passo para iniciar um projeto deveria se ser o entendimento da situação problema. Isso se daria através da observação constante e um olhar crítico ao objeto que se desejava criar ou melhorar, assim como o contexto em que ele está inserido. Ela ressalta a importância de se estudar o passado - como os problemas eram resolvidos anteriormente - e o presente - como eles estando sendo resolvidos agora - para então identificar oportunidades de melhorias nas soluções deste problema, tendo isso identificado é papel do designer criar essas soluções de forma criativa.

Priscila ressalta a importância de não olhar apenas o "o que" foi feito, mas o "como" e o "por que" foi feito. Priscila argumenta que ao pensar em sapato, um artigo existente há milhares de anos, é importante entender ao longo da história da humanidade como este produto foi concebido e utilizado dentro de cada contexto e observar os diversos fatores de forma ampla como: existência de matéria-prima, viabilidade econômica, necessidades para proteção, prática de esportes ou item de diferenciação cultural.

No caso estudado, a empresária também buscou entender os modelos de negócios adotados pelos concorrentes, suas linguagens e identidade de marca, assim como os processos produtivos adotados. Ou seja, pensando nos métodos de administração de empresas, a designer realizou um estudo de benchmark. Para entender as outras etapas da cadeia de valor, a empresária entrou em contato com outros profissionais da área, tanto de empresas bemsucedidas, como também empresários de negócios que faliram. Ela destaca a importância de buscar esse conhecimento no relato de quem vivenciou a indústria, inclusive para ver o que não deu certo, e ter um olhar atento para entender os porquês, questões estas que nem sempre são explícitas. É importante observar que a empreendedora nunca tinha a intenção de replicar nenhum modelo ou ação previamente executada, ela observa e aprendia com essas experiências e elabora ações próprias derivadas destes conhecimentos adquiridos.

Durante o seu processo de pesquisa, a designer realizou uma extensa viagem por dois importantes mercados consumidores e produtores de calçados e artigos de vestuário: a China e a Índia. Quando questionada sobre a importância das viagens de pesquisa, a empresária 
explica que este é um momento para analisar com “outros olhos' os problemas que deseja estudar, é uma imersão em uma nova realidade que amplia a forma como você enxerga um problema e suas soluções. Priscila defende que é importante "viver a história e não simplesmente ouvir alguém contá-la”.

Priscila Callegari comenta que analisando a forma de trabalho de alguns de seus funcionários de gerações mais recentes, percebia um excesso de confiança em pesquisas online. A empresária entende que o acesso alcançado pela internet é imenso, mas ao seu ver, o conhecimento adquirido é diferente da imersão no assunto a ser estudado. Normalmente as informações encontradas na internet são filtradas, não podendo ser substituídas pela observação e vivência. Dentro deste contexto, Priscila ainda ressalta a importância de entender o cenário como um todo e para isso é necessário desenvolver seus conhecimentos de forma ampla e interdisciplinar. Segundo o teórico do design, Claudio Ferlauto (2002), cultura geral, conhecimentos da história da arte, conhecimentos da história do país e da industrialização são armas fundamentais na guerra do mercado e exercício profissional consciente. $\mathrm{O}$ autor defende que cultura tem a ver com curiosidade intelectual e conclui que "criar é fazer escolhas. Criar é relacionar dados antes nunca associados" (Ferlauto, 2002, p.83).

Pedroso (2016) ressalta que nesta etapa de análise externa, entender restrições legais, sociais e ambientais é um fator essencial para identificar oportunidades e ameaças do setor em que se pretende atuar. Do ponto de vista ambiental, Priscila se incomodava com algumas características da indústria calçadista. Em sua imersão na indústria viu, por exemplo, que o processo envolvia uma utilização intensa de mão-de-obra, além de agregar diversas indústrias adjacente de componentes como couros, solados, saltos, fivelas, tecidos, entre outros. A designer relata que, considerando toda a cadeira, um calçado pode passar por até 200 mãos para ser finalizado. A indústria como um todo era poluente, pois utiliza materiais com descarte complexo - os diversos componentes do calçado não são facilmente desmontáveis e separados para reciclagem - e a maioria destes materiais não se decompõe rapidamente, como borrachas, metais e plásticos. A designer identificou que isso era muito contraditório com o conceito padrão de um produto de moda que é sazonal, ou seja, pode se tornar obsoleto em ciclos rápidos encurtando seu tempo de uso. Para ela era um fato perturbador criar um artigo que tivesse tanto trabalho humano e recursos naturais para ser produzido e descartado rapidamente. 
Lições aprendidas:

- Não adianta dar uma solução se você não souber com clareza qual é o problema. Para a designer, as etapas de estudo do contexto passado e presente da situação-problema não podem ser puladas na elaboração de qualquer projeto, seja o design de uma luminária ou a criação de uma empresa.

- Toda empresa precisa ter uma expectativa do futuro para tomar decisões estratégias, porém o futuro é sempre incerto, o risco é inerente. Neste contexto, entender o passado e observar o presente são as formas que um profissional tem de projetar um futuro esperado. Priscila argumenta que o designer é um profissional treinado para ter a capacidade de identificar necessidades não atendidas ou mal atendidas e a partir deste conhecimento gerar soluções criativas para saciá-las.

- Inovar implica ter uma ideia original. Pode-se questionar então de onde vêm esse insight criativo de um designer ou empreendedor. Priscila argumenta que "original tem a ver com origem". O estudo da concorrência deve ser realizado para que se tenha elementos para poder criar e não para se copiar. A designer é enfática em dizer que os novos empreendedores não deveriam copiar, deviam se inspirar em ideias e buscar solucionar necessidades não atendidas pelos seus concorrentes buscando seus próprios caminhos. Corroborando com esta ideia temos o autor Ferlauto (2002) que define que criar algo original é conectar ideias de forma nunca antes relacionadas. No caso de Priscila, foram ideias como: customização, sapatos, materiais naturais nacionais, capacidade ociosa da indústria e varejo experiencial.

- O que pode ser entendido como restrição para alguns negócios pode ser entendido como oportunidade para outros. No caso, o fato da indústria calçadista gerar muitos resíduos durante o seu processo produtivo, bem como a lógica de descarte do produto após o uso, eram fatores que incomodavam a empreendedora em um nível pessoal. Criar um negócio que provesse uma solução para essa indústria poluente se tornou uma motivação para a empresária. Ou seja, uma solução que fosse ambientalmente responsável, comercialmente viável e pessoalmente satisfatória.

\subsection{Análise Interna}


Essa é uma etapa de análise objetiva sobre as questões relevantes e as variáveis de decisão relacionadas ao ambiente interno da organização, seus pontos fortes e suas vulnerabilidades. Pedroso (2016) coloca que alguns desses pontos são: processos e atividades, produtos e serviços oferecidos, governança corporativa, estrutura organizacional, cultura e estrutura de poder.

Em um contexto de empreendedorismo, o indivíduo empreendedor é a peça central de uma organização, que neste caso ainda não está estruturada, ela está em processo de construção. Ao nos aprofundarmos no processo de criação da empresa, observamos que a empreendedora refletia sobre os impactos das suas decisões empresariais na sua vida pessoal, assim como seus vínculos familiares também influenciavam as suas decisões.

A empreendedora relata que o processo de empreender tem um grande impacto na dinâmica da família, pois a criação de um negócio envolve extensa dedicação de tempo, atenção e recursos financeiros. Priscila argumenta que empreender envolve riscos e mesmo que o capital inicial fosse originário do seu próprio negócio anterior, por estar dentro de um casamento, esta decisão significava a realocação de um recurso comum da família. Ela destaca que seu companheiro sempre a incentivou e que este apoio foi determinante no projeto, tanto do ponto de vista financeiro como também motivacional.

A designer descreve que apesar deste apoio, o processo de concepção do novo negócio foi bem solitário. No seu círculo próximo não haviam outros empreendedores com quem dividir experiências ou mesmo profissionais que atuassem nas áreas calçadista ou varejista para se discutir questões técnicas e específicas do negócio.

Uma forma de suprir esse convívio e possibilidade de discussão dos temas, foi a sua participação no programa Empretec realizado no SEBRAE (Serviço Brasileiro de Apoio às Micro e Pequenas Empresas), curso que visa a capacitação de empreendedores. A designer afirma que essa decisão foi importantíssima para que ela passasse a se enxergar como empresária. Em geral, ela avalia que o curso a ajudou, pois foi um momento importante de dedicação à analise de aspectos concretos do negócio que estava criando, como preços e custos. Outro fator que ela ressalta é a importância dos colegas para o aproveitamento do custo, já que esse era um dos objetivos principais: ter trocas de experiências com outros empreendedores. 
A empresária afirma ter sido um programa rico em experiências e conhecimento, porém ressalta uma crítica ao formato do curso. A designer descreve que o curso foi moldado para a abertura de uma empresa padrão, com aplicação de métodos de ensino repetitivos. Ao seu ver, não haviam recursos didáticos que apoiassem a criação de um negócio criativo ou inovador.

Além deste curso, para aprimorar suas habilidades como empresária, Priscila entendia a necessidade de se especializar no design de calçados. Para isso realizou um curso no IED (Instituto Europeu de Design) em São Paulo. Porém sentiu que o curso não permitiu o entendimento aprofundado da indústria, pois fragmentava a etapa de criação de produtos, sem dar a devida atenção ao restante do processo. Não permitia o conhecimento da cadeia de valor desse produto, questão que a empresária considerava essencial para poder tomar suas decisões estratégicas.

Buscando entender o restante da cadeira produtiva, Priscila buscou o SENAI (Serviço Nacional de Aprendizagem Industrial). Não havia um curso formatado e sim o apoio técnico ao desenvolvimento de projetos. Porém a designer descreve que o processo permitiu que ela tivesse uma vivência da realidade de uma fábrica, podendo conhecer a fundo as máquinas, os métodos, os processos e os materiais empregados nesta indústria. Ela conclui que foi como uma verdadeira pós-graduação na área.

Priscila buscou primeiro o SENAI da cidade de São Paulo, mas por se tratar de um projeto ambicioso na área calçadista, a unidade da capital indicou que ela procurasse o SENAI da cidade de Franca, importante polo produtor de calçados no interior do estado paulista. Esta unidade tinha profissionais e equipamentos específicos para a indústria calçadista. A designer relata, que seu projeto acabou sendo um grande desafio para o SENAI, pois este não costumava realizar um trabalho desta natureza, que subvertia alguns caminhos comuns dos produtores de calçados, em especial no processo criativo. Na visão da empresária, a instituição costumava prestar trabalhos para a indústria com foco em melhorias produtivas, em geral melhorias incrementais e não disruptivas. As ações estudadas eram pensadas em como ser mais eficientes e não necessariamente mais eficazes.

Priscila defende que essa experiência de entendimento técnico da cadeia produtiva foi um dos pontos mais importantes do processo de criação da empresa. Foi uma etapa de imersão. Por ser longe de São Paulo, onde morava - Franca fica a $600 \mathrm{~km}$ da capital - ir para a cidade a obrigava a focar unicamente no projeto. Foi uma etapa longa que durou mais de um ano, pois 
envolvia as burocracias da instituição, as férias da equipe da unidade, as aprovações para uso de equipamentos e também de orçamentos.

Neste momento, Priscila ressalta a importância do tempo, e como esse fator é chave para a criação de uma empresa consistente. Segundo a designer, o tempo permite o aprendizado de novas habilidades, a realização de diversas tentativas - incluindo erros e acertos - e o próprio amadurecimento de ideia.

Citando exemplos de sua experiência anterior como designer gráfica, ela relata o caso da criação de um logo. Para a designer mesmo que durante o briefing de um cliente surgisse imediatamente uma ideia para solucionar sua demanda, ela não apresentava esta ideia na mesma hora. A designer entendia que toda ideia precisa de um tempo de maturação, ela precisa ser testada e checada de vários ângulos. Ela fazia isso de forma prática, imprimindo e prendendo o logo na parede para que o visse todos dias, então o guardava para revê-lo só depois de uma semana. Esse processo era importante para confirmar se essa atração inicial pela ideia continuava fazendo sentido após o passar tempo e a recorrência.

Ainda neste exemplo, a designer explica que sempre buscava outros caminhos, ou seja, vasculhava as alternativas. Podemos fazer um paralelo deste processo com a etapa defendida por autores da teoria da decisão, como Herbert Simon (1965). Priscila relata que muitas vezes confirmava que o primeiro caminho era o ideal, mas mesmo assim, o processo e o tempo eram necessários para chegar nesta resposta. Pelas suas próprias palavras: "você tem que lutar contra ele para encontrar com ele de novo". Priscila diz que aprendeu esse método trabalhando como designer e defende que o processo de discordar de uma ideia e tentar destruí-la, é uma forma de se descobrir os argumentos para defendê-la novamente. Se após este processo ela ainda fizer sentido, é porque a ideia é redonda, e se ela é redonda é fácil vender para o cliente. Ela conclui sua argumentação dizendo que no processo de empreender isso acontece da mesma forma e para isso é necessário tempo. Segundo a designer: "o tempo é um aliado fundamental no processo criativo".

Continuando a análise interna, a empresária entendia a importância de se montar uma equipe. Sua equipe inicial consistia em uma funcionária de confiança que cuidava da parte administrativa, esta já era funcionária da empresa anterior e as suas aptidões para esta área eram comuns aos dois negócios. Já para a parte específica do setor calçadista, por mais que a designer tivesse estudado o assunto, considerou importante ter um profissional com 
experiência prática no setor. Para isso, buscou contato com outros profissionais da sua rede de contatos da carreira anterior, assim como pedindo indicação para os fabricantes de sapatos. Dessa forma, chegou a sua primeira assistente de produto. Essa profissional, já havia trabalhado em uma das marcas de sapatos que era referência no estudo previamente realizado, tendo alguns conhecimentos importante, não apenas de questões técnicas e operacionais, mas conhecimentos internos do mercado almejado.

Outro fator importante na análise interna da empresa, é entender sua estrutura de poder. Questionada sobre esse assunto, Priscila diz que atuar em uma organização em que ela era a tomadora de decisões foi um grande prazer. A empresária defende que ter tido a possibilidade de ser sua própria chefe e sua própria cliente foi o que possibilitou viabilizar esse projeto. Existiam riscos, mas ela podia assumir estes riscos. Conforme Nitzche (2012) coloca, as empresas são avessas a riscos, e temem a ambiguidade de resultados de uma ideia inédita, isso faz com que elas percam seu senso do possível, ou seja, inibam sua criatividade. O pensamento do design busca quebrar essa lógica e inovar.

A empreendedora explica que tendo sua própria empresa não precisaria dar satisfação para outros, mas ela sentia que precisava dar satisfação para si mesma, sentia a obrigação de fazer o projeto dar certo. Ela entende que existiu um fator pessoal de auto exigência, a designer diz exigir mais de si do que dos outros. Para a empresária, a junção desse rigor em se auto exigir profissionalmente e ao mesmo tempo ter liberdade de errar, acertar, interromper e retomar, são os fatores que permitem um empreendedor inovar e alcançar o sucesso.

Sobre a estrutura financeira da empresa, Callegari relata que sempre teve uma grande dificuldade em fazer cálculos financeiros, era algo que a incomodava. Contudo, ela não enxerga que isso foi necessariamente um ponto fraco. A empresária acredita que se tivesse considerado minunciosamente cada investimento, provavelmente o projeto teria travado e não teria sido concretizado. Ela argumenta que se tentasse calcular a taxa de retorno de cada ação no momento de elaboração, é possível que o projeto não parecesse viável. Segundo a designer, o processo de criação envolve erros e desperdícios, que são parte do processo. Além do fator tempo, que se observado por teorias econômico administrativa pode ser calculado como perdas financeiras, conhecidas como custos de oportunidade, ou seja, o quanto ela estaria ganhando se estivesse dedicada a uma outra atividade. Por exemplo, o quanto ela estaria deixando de ganhar investindo em criar sua própria empresa ao invés de ser diretora de 
arte de uma agência de publicidade. Na visão da empreendedora, isso seria um fator de angústia pessoal, que a imobilizaria no processo criativo e inovador da empresa. Para ela, se este fator de retorno calculável for priorizado, as empresas não inovam e acabam optando por investir naquilo que já foi provado, ou seja, a busca excessiva por mitigar riscos inibe a inovação. Para Callegari, inovar sempre envolverá riscos.

Pode se observar que o pensamento da empreendedora se aproxima das teorias de design. Segundo Nitzche (2012) o processo de design oferece uma maneira de manter as coisas em movimento sem um fechamento prematuro, uma capacidade de compreender a ambiguidade das mudanças e perceber que elas são oportunidades criativas, não sementes para a paralisia, ou seja, não pode se ter medo de assumir riscos de uma inovação que não tem garantias dos seus resultados. Uma análise totalmente analítica quantitativa, tiraria esse senso do possível, pois sem benchmarks não se pode calcular uma possível taxa de retorno. Isso pode levar a conclusão errônea de que uma empresária com pensamento de designer realizasse suas decisões, sem considerar fatores concretos, Priscila mostrou em sua trajetória que tem consciência do seu papel de empresária e que uma organização deve ser sustentável e gerar lucros. A designer ressalta que durante esse processo de criação da estratégia da empresa se manteve abertas as possibilidades, mas sempre havia uma racionalidade em suas decisões, apesar de não ser feito uma conta na "ponta do lápis", havia sempre um entendimento de nãodesperdício e otimização de recursos. Novamente, este pensamento é suportado pela teoria de design aplicado na gestão, Nitzche (2012) explica que o pensamento de design não descarta o pensamento racional, o planejamento e a solução criativa para atender uma necessidade identificada deve utilizar de forma coerente os recursos acessíveis.

\section{Lições aprendidas:}

- Empreender é uma atividade que demanda grande dedicação de tempo e recursos. A atividade profissional interseciona com a vivência pessoal e familiar. Desta forma, os impactos da criação de uma empresa não conseguem ser isolados, a harmonização dessas duas esferas é necessária.

- É importante que um empreendedor tenha uma rede de contatos com que possa discutir suas ideias e melhorar a sua tomada de decisões. Essa rede deve conter pessoas que entendam de fato a realidade empresarial para que sejam de fato conversas construtivas e não palpites. Quando não há indivíduos com este perfil 
próximos ao empreendedor, é interessante buscar caminhos alternativos, como instituições de apoio a empresários e cursos da área que deseja atuar. Esse relato mostra uma convergência com o estudo de Huang (2009) que diz que no caso de pequenas e médias empresas há uma preferência por buscar informações fora da empresa ao invés de dentro, destacando a importância da rede de relacionamento do empresário.

- Muitos cursos tem um formato que visa o desenvolvimento de habilidades que melhoram a eficiência das atividades, mas não a eficácia. Pessoas eficientes desenvolvem bem um processo e as eficazes tomam melhores decisões. Ou seja, para se chegar a um destino desejado, mais importante que andar rápido é saber para onde andar. Pelo relato descrito por Priscila, as habilidades desenvolvidas nos cursos trazem melhorias incrementais e não disruptivas. Para inovar devemos buscar melhorias disruptivas, descobrir novos caminhos, novos meios de transportes ou atalhos antes não explorados.

- O processo de criação de uma ideia inovadora tem que ter um amadurecimento. Ela não pode ser executada precipitadamente. Seja na criação de uma empresa ou de um produto de design gráfico como citado no exemplo de Priscila. Uma decisão estratégica tem que ser sedimentada, tem que ser discutida com outras pessoas. Conforme a sugestão da designer, ao tentar destruir a sua própria ideia, você consegue construir argumentos para defendê-la.

- A criação e a operação de uma empresa não se fazem sozinhas, contar com um bom time é fundamental. Portanto, é necessário buscar profissionais que complementem as habilidades que o empreendedor não possui ou não tem tempo de executar. Priscila afirma: "contrate uma pessoa que seja melhor que você na atividade que ela vai executar".

- Em relação a estrutura de poder, o empreendedor tem a vantagem de ser o tomador das decisões estratégicas. Sem uma hierarquia complexa e sem superiores a quem se reportar, suas decisões podem ser realizadas de forma ágil e livre. Essa liberdade pode ser paralisante para alguns, pois não há com quem dividir as responsabilidades da tomada de decisão, os riscos são assumidos integralmente por este indivíduo. No caso de Priscila ela considerou isso um prazer e como designer, sempre foi inovadora. 
Como estruturava bem suas ideias, por mais que houvessem riscos ela se sentia tranquila em assumi-los.

- O perfil do empreendedor é fundamental para o seu sucesso. Por não precisar se reportar a ninguém, há o risco do profissional perder o foco e não ter exigência de excelência nas suas atividades. Observando o caso da empreendedora da Ciao Mao, nota-se que ela possuía uma combinação de liberdade criativa, que a permitia inovar, com um rigor profissional, que a mantinha no foco. Assim como tinha resiliência para conseguir sobrepujar os erros cometidos e desafios impostos na trajetória da criação da sua empresa. Isso tem convergência com o que é defendido por Huang (2009) que diz que as características pessoais do proprietário da empresa são fatores que influenciam diretamente as decisões estratégicas da empresa.

- No processo de inovar, o excesso de zelo, a busca por mitigar riscos e a expectativa de taxas de retorno concretas, podem paralisar a criação de uma empresa. Inovar é assumir riscos, mas gerir uma empresa é ser racional com a sua capacidade de gerar lucros com os recursos disponíveis. É necessário que o empreendedor balanceia esses dois pensamentos: viabilizar a existência da empresa sem perder o senso do possível.

\subsection{Intenção estratégica}

Pela proposta de Pedroso (2016) essa etapa é formada pela tríade: missão, visão e valores, reflete os propósitos e as aspirações de uma organização.

Ao analisar a trajetória da empreendedora, é possível notar que a empresa não surgiu com esses três pontos definidos com essa nomenclatura, mas os valores organizacionais e crenças básicas existiram desde seu início e traçaram todo o desenvolvimento da estratégia da Ciao Mao.

A empreendedora explica que não havia um manifesto explícito de missão, visão e valores da empresa, mas existia um conceito de caráter e valores interno dela, que ela chama de filosofia de vida, e que se permeava em todas as decisões que ela tomava para essa empresa nascente. Priscila acredita que a empresa é um reflexo de seu criador, e consequentemente a cultura empresarial replica a forma de agir de seu dirigente. 
Apesar de não ter ocorrido no momento de abertura da empresa, eventualmente as intenções estratégicas foram formalmente descritas. Seis anos após a fundação, a empresa passou por um processo de revisitação do seu branding com a consultoria da empresa Rizoma. O resultado deste trabalho descreveu como quatro pontos ao invés da tradicional tríade, mas que também refletem os propósitos e ambições da empresa. Esses foram chamados de: (a) Crença, (b) Propósito, (c) Valores e Atributos e (d) Ambição.

A crença da empresa se definiu como: "É possível ver e transformar o mundo com design original". O propósito: "fazer e promover design que valorize o múltiplo e singular de cada um”. Os valores e atributos foram divididos em 5 pontos e são descritos no site da empresa:

"DESIGN ORIGINAL para ver e transformar o mundo. Na Ciao Mao, Design é um jeito poderoso de enxergar a realidade e encontrar soluções inspiradoras para as pessoas e para o mundo. Não é só forma, é também função. É ética e estética.

BRASILIDADE para celebrar a diversidade. A Ciao Mao tem alma global e, por isso, valoriza sua raiz brasileira: uma cultura híbrida, plural e rica em relações e referências; reconhecida pelo jeito espontâneo, criativo e alegre de viver a vida.

CURADORIA E CO-CRIAÇÃO para caminhar com personalidade. Buscamos inspirar caminhos e propor relações interativas para expandir as possibilidades de auto expressão. A diversidade de modelos exclusivos e o processo lúdico de customização, reforçam nosso desejo de criar experiências únicas e memoráveis.

QUALIDADE E CONFORTO para o bem-estar físico e emocional. Para nós qualidade e conforto são fundamentais. Uma questão de bem-estar físico: design ergonômico e materiais de alta qualidade. E também uma questão de conforto emocional: é bem feito, veste bem e expressa bom gosto!

REDE SUSTENTÁVEL para deixar uma pegada boa. Investimos no uso criativo e sustentável dos materiais, na renovação inteligente dos produtos e no respeito a todas as pessoas e organizações com quem nos relacionamos. Acreditamos na importância de se adotar uma visão sistêmica que considera todo o processo de criação de valor: da produção ao pós-venda." (CIAO MAO, 2017)

A ambição se assemelha com a visão, que representa o que a empresa deseja no futuro e qual a sua posição almejada. A empresa descreveu essa ambição como: "Ser a marca brasileira referência em design original de calçados, acessórios e varejo experiencial, ao promover relações de curadoria e co-criação com as pessoas". 
Vemos então que apesar da empreendedora não ter descrito a missão, visão e valores da empresa como um manifesto, ela tinha bem definido os propósitos e as aspirações que determinariam a trajetória da sua empresa desde o início.

É possível notar que os valores representam bem as tendências que Priscila identificou nos seus estudos de mercado. Durante a entrevista pessoal realizada com a empreendedora, para entender a forma de definição de valores foram discutidos brevemente os casos de duas outras empresas. Segundo G1 (2015), o caso do Suco do Bem, que vendia a ideia de um produto feito a partir da compra de frutas de pequenos agricultores locais, e o da Diletto, que dizia fabricar sorvetes artesanais seguindo receitas italianas da família do fundador. Em ambos os casos esses atributos divulgados como valores de marca foram desmentidos pela mídia e explicitados como incoerentes com as reais ações das empresas. A primeira tinha contrato com grandes fornecedores industriais de suco e a segunda era uma história fictícia criada como ferramenta publicitária, mas defendida como real pelo fundador. Priscila, argumenta que para ela, esses casos são de empresas que nasceram focadas no marketing, incluindo sua declaração de missão, visão e valores, neste caso, não são reflexos da cultura empresarial, mas sim textos publicitários. A empreendedora finaliza dizendo que a Ciao Mao é para ela um trabalho de realização da alma, por isso é autêntico, não é a simples busca de copiar um benchmark ou preencher uma lacuna do mercado.

\section{Lições aprendidas:}

- A criação de uma empresa não deveria partir de uma idealização de missão, visão e valores. O desenvolvimento desses conceitos são consequências da solução encontradas para resolver a situação problema. Assim sendo, conforme descrito nos subcapítulos anteriores, o processo de análise externa permitiu o entendimento da situação problema e o processo de análise interna permitiu o uso criativo das habilidades da empresa para a solução do problema. As respostas encontradas no decorrer dessas duas etapas é que fundamentarão os conceitos de missão, visão e valores da organização.

- Algumas organizações não têm essa tríade de conceitos bem definida. No caso de um empreendedor, normalmente a empresa é reflexos de sua própria personalidade. No caso da Ciao Mao, a questão de sustentabilidade não era um conceito visto apenas como uma tendência de mercado, era um assunto que tinha especial valor para a 
empreendedora na sua vida pessoal, e isso refletiu nas decisões tomadas para sua empresa.

\subsection{Posicionamento Estratégico}

O trabalho de Pedroso (2016) descreve essa etapa tendo dois conjuntos de decisões. Um é o posicionamento competitivo, que determina a posição da organização e sua marca perante os seus concorrentes. O segundo define o conjunto de benefícios a ser entregue aos clientes por meio de produtos e serviços da empresa, levando em consideração o patamar de preço. $\mathrm{O}$ autor levanta uma série de questionamentos que ajudam a definir a proposta de valor para a empresa: "qual a tarefa a ser feita? Em outras palavras, quais os problemas importantes ou necessidades dos clientes devem ser resolvidos? Quais os benefícios? De que forma os produtos e serviços oferecidos resolvem o problema dos clientes? Quais são os diferenciais da organização? Ou seja, o que a organização faz diferente ou melhor que seus concorrentes?" (Pedroso, 2016, p. 111).

DECISÃO: Atuar com um produto classificado como premium

Em relação ao posicionamento de mercado a ser adotado, Priscila diz que a sua premissa inicial era fazer um produto de qualidade e não necessariamente a faixa de preço praticada, o preço era uma consequência. Essa decisão veio da análise da cadeia produtiva de calçados, desde entender a alta demanda de mão-de-obra para produção, os custos da manufatura no Brasil, as dificuldades de produzir calçados em pequena escala e os impactos ambientais do processo. Para ela não faria sentido se utilizar de todo esse processo para criar um produto com materiais barato de baixa qualidade que tivessem rápido descarte.

Decidiu-se então produzir um produto com características que o tornasse atemporal esteticamente e que fosse produzido com materiais de qualidade. Fabricar esse produto no Brasil envolvia custos bem mais altos que a média do calçado brasileiro já que eram consideradas: mão-de-obra especializada, materiais de qualidade com preocupação ambiental (a CIAO MAO utiliza, por exemplo, borracha reciclada nos solados, provenientes de indústrias nacionais) e produção em pequena quantidades, o que impede redução de custo através ganhos de escala. 
Revisitando esses pontos, a empreendedora se lembra de ter tido pouca orientação sobre precificação nos cursos que realizou. A designer argumenta que no seu pensamento inicial, o valor não estava relacionado apenas nos custos diretos do produto, estava também no seu processo produtivo e seus impactos. Segundo ela, há valor em não poluir, não descartar um produto precocemente e não gastar energia desnecessariamente. A empreendedora acreditava que existiam consumidores que apreciariam e pagariam por esses valores agregados que extrapolavam o produto físico.

Priscila relata que a decisão de posicionamento estratégico foi baseada nesta crença conceitual e que não realizou uma pesquisa formal de preços praticados pela concorrência. Ela reconhece neste ponto que a estratégia poderia ter sido mais assertiva se tivesse sido feito este estudo prévio de mercado, mas ressalta que não havia benchmarks com produtos com a mesma proposta, o que dificultava as comparações. A empreendedora também argumenta, que por ser um produto entendido como diferente do padrão produzido, na negociação com fornecedores não era possível definir preços previamente, pois dado o pequeno volume e complexidade, eles só calculavam os custos após as primeiras produções. Ela relata que se houvesse insistência neste quesito de controle rígido de preços o fornecedor recuaria e neste momento a prioridade era concretizar o projeto e ter os primeiros produtos disponíveis para comercialização, não se poderia colocar o custo como restritivo. Ela entendia que os ajustes poderiam vir em um próximo momento.

Isso de fato ocorreu, pois com o decorrer do funcionamento da empresa, as produções se tornaram contínuas, o que permitiu abrir novos fornecedores, estudar novos materiais e assim como testar novas formas produtivas. O trabalho de estudo de mercado e definição de métodos de precificação também foi realizada posteriormente com a entrada de um funcionário com conhecimentos de marketing e economia.

O relato técnico apresentado no EMPRAD (Encontro dos Mestrados Profissionais em Administração) por Hayashi (2016) faz um paralelo entre o posicionamento estratégico empregado na Ciao Mao com a teoria do Oceano Azul proposto por Kim e Mauborgne (2005). A teoria do Oceano Azul propõe que as empresas evitem os ambientes hipercompetitivos ('oceanos vermelhos') e criem uma proposta de valor que diferencie a empresa dos demais concorrentes, evitando a competição com base apenas em preço. A organização que busca implantar o Oceano Azul deve identificar características que agregam 
ou não valor para os clientes, eliminando o custo das características pouco importantes e apresentando melhorias naquelas de maior valor. Os autores propõem uma ferramenta que compara e indica possíveis estratégias frente à concorrência: a curva de valor. A curva de valor é composta pelos elementos-chave que os clientes consideram ao decidir sobre o produto a comprar e como cada elemento é oferecido atualmente pela concorrência. Abaixo a curva de valor proposta para o caso da Ciao Mao:

Oceano Azul

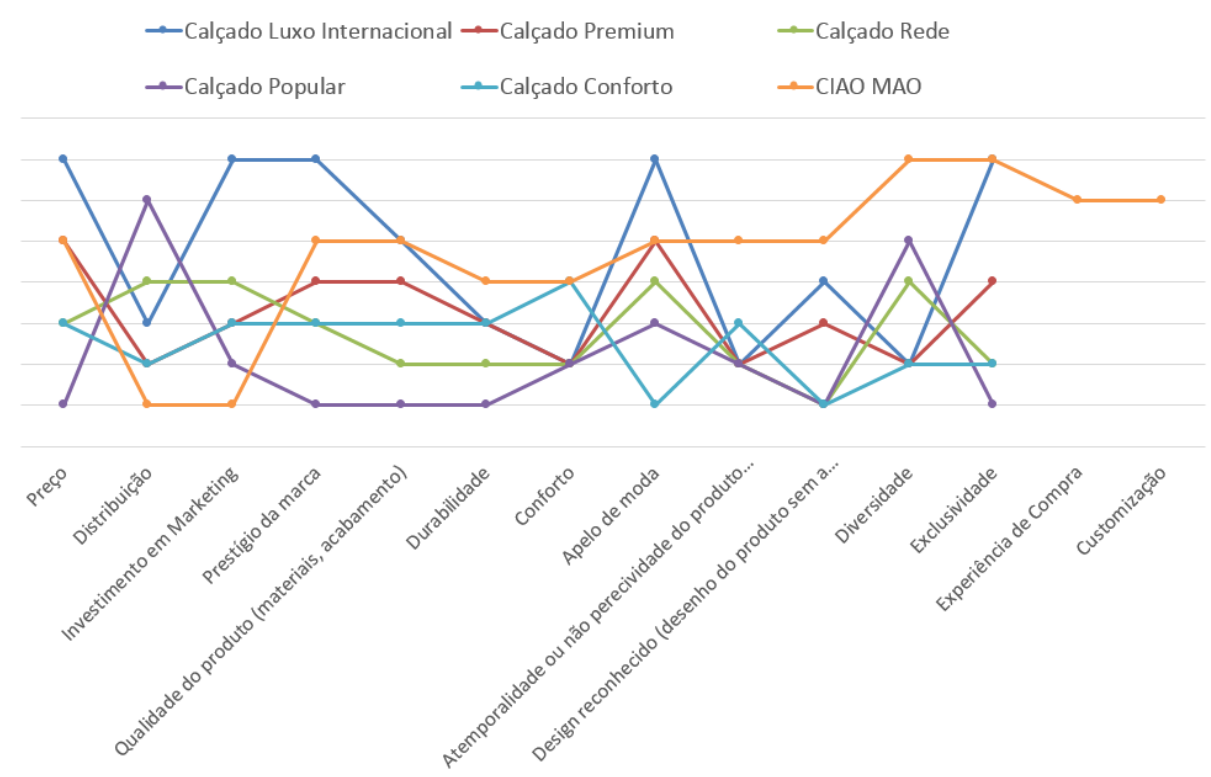

Figura 9 - Curva de valor da Ciao Mao

FONTE: HAYASHI (2016)

Segundo o relato técnico de Hayashi (2016) para viabilizar todos os diferenciais da marca, foi necessário que a empresa estabelecesse um posicionamento de preço premium - também chamado de "luxo intermediário" no trabalho de Duarte (2013) - com produtos que apresentam valor final de $\mathrm{R} \$ 350$ a $\mathrm{R} \$ 1.000$. Esse posicionamento estava de acordo com o mercado alvo que se desejava atingir e se justificava por ser um produto de alta qualidade, feito com matérias-primas nobres e em pequenas quantidades, disponível em pontos de vendas selecionados e com atendimento de profissionais de alto padrão.

Quando questionada se pensou em uma classificação tradicional de público alvo (faixa etária, gênero, classe social), Priscila responde que focou no público feminino, pois conforme relatado na etapa 2 já percebia a existência dessas possíveis clientes, porém pensou de uma forma menos objetiva nos demais critérios como idade, ela se pautando, portanto mais nas 
características comportamentais destes clientes. A designer os descreve como: "pessoas que tivessem cultura, viajadas, pessoas que tivessem noção do que acontecia no mundo. Era buscar pessoas que quisessem entender o que de fato estavam consumindo, questionassem quem estava fabricando seus sapatos, a durabilidade deles e o conforto". Segundo Priscila Callegari: "São pessoas que tem cabeça e não só pés".

Sobre a concorrência do mercado, a designer olhou amplamente o mercado. Quem estava dando certo e qual a história por trás. Não apenas no Brasil como também no exterior. Estudou por exemplo o caso de marcas como a espanhol Camper e alemã Trippen, avaliando a estratégia delas e as diversas etapas que enfrentaram no decorrer do crescimento, tanto em termos de desafios comerciais como produtivos. A inspiração por essas marcas era para entender suas histórias e nunca para copiar seus desenhos.

Através de suas pesquisas, a designer identificava diversas tendências que corroboravam com a ideia que havia pensado. Existia uma busca e valorização do bem estar, com marcas de diversos segmentos se destacando com esses valores. Havia também a questão da mulher quebrando normais culturais pré-estabelecidas, como a associação de elegância com a utilização de salto, Priscila enxergava que a importância do conforto no caminhar estava começando a ser discutida e valorizada e que o uso de calçados altos e desconfortáveis estava deixando de fazer sentido para muitas mulheres.

\section{Lições aprendidas:}

- O conceito de usar o preço como um balizador de posicionamento não é sustentável. A precificação do produto tem que partir da qualidade, sendo uma consequência do que o produto oferece. $\mathrm{Na}$ visão da designer, criar um produto que solucione diversos problemas é o que o torna valioso. A solução não é apenas para o cliente, é também para os demais participantes da cadeia de valor assim como os impactos sobre o meio ambiente. O produto Ciao Mao busca otimizar recursos, utilizar matéria-prima de origem confiável com baixo impacto ambiental, remunerar adequadamente a mão-deobra envolvida, da fábrica à loja, assim como permitir um uso intenso do produto inibindo o seu descarte prematuro. É essa soma de qualidades que geram o valor do produto. 
- Definir o público alvo e entender este público é fundamental. Isso não precisa ser feito com fórmulas padrão como definição de faixa etária ou gênero. $O$ importante é encontrar um público que veja valor no produto que a empresa deseja oferecer e que esteja disposto a pagar por ele. No caso dos sapatos Ciao Mao, clientes que enxergassem valor que ultrapassasse as questões de moda e sim os valores acumulados durante toda a cadeia produtiva.

- É importante que as ações da empresa sejam coerentes com a estratégia adotada e sejam adequadas aos valores propostos. Não adianta defender o conceito de sustentabilidade na ponta do varejo e se se utilizar de matérias-primas com processos produtivos poluentes, por exemplo. Por outro lado, se a situação-problema que a empresa desejasse resolver fosse a oferta de calçados de baixo custo, a estratégia seria outra. O importante neste contexto é a coerência entre a proposta e a execução.

\subsection{Modelo de Negócio}

Nesta etapa se define a forma como a organização deve ser estruturada com o objetivo de criar, entregar e capturar valor. Segundo Pedroso (2016), a adoção dos preceitos de modelagem de negócios tem como objetivos: projetar e analisar uma empresa de forma coerente e integrada; identificar quais elementos da organização devem se alterar ou desenvolver de modo a atender as principais decisões estratégicas.

Após a criação do conceito do produto, haviam algumas decisões a serem tomadas de como viabilizar o projeto. A cadeia de valor dos calçados pode ser resumida como tendo três etapas principais: (a) fabricação; (b) gestão de marca e criação de produtos; e (c) vendas. Priscila já havia criado a marca e seus produtos, precisava então tomar as decisões de como produzir e quem deveria produzir, depois como vender e quem deveria vender.

Avaliando o primeiro passo da cadeira de valor: a fabricação. A empreendedora decidiu não assumir esta parte da cadeia de valor do produto e sim buscar parceiros produtivos. A empresária identificou que havia capacidade ociosa nas fábricas montadoras de calçados, existindo uma oportunidade para achar um fornecedor fabril. Assim poderia focar nas suas outras expertises, que não eram industriais. 
Priscila relata que identificou nos seus estudos sobre o setor, que a indústria calçadista estava em crise, muitas fábricas tinham fechado e outras estavam com capacidade produtiva ociosa. Nas décadas anteriores, a indústria calçadista brasileira tinha vivido seu auge, impulsionada pela exportação de produtos, em especial aqueles de baixo valor agregado para os mercados americanos e europeu. A China fez um grande movimento de entrada neste setor, segundo relato da empreendedora, muitos profissionais brasileiros foram contratados como consultores de empresas chinesas para fazer setup de fábricas e passar know-how da área. Uma estratégia bem-sucedida para a China e que acabou por crescer no mercado internacional e atingir irreparavelmente a indústria brasileira. Como no calçado a principal parcela de custo está ligada a mão-de-obra, a competição chinesa com estes custos baixos dominou o mercado e retirou grande parte dos clientes brasileiros. Não era mais possível competir com preço em escala mundial. As fábricas brasileiras estavam buscando novos caminhos, seja explorando mercado nacional, como estavam fazendo as grandes redes varejistas de calçados, seja abrindo sua produção para confecção de produtos de marcas terceiras, modelo conhecido como private label, que foi o modelo adotado para a produção de sapatos Ciao Mao.

Ainda tratando desta etapa produtiva, a produção de um calçado envolve muitos componentes: couro, borracha, solado, sola, biqueira termoplástica, aviamentos, ferragens, formas, facas, palmilhas, etc. Cada um desses elementos tem fornecedores próprios especializados, é necessário definir cada um deles e depois agregar esses componentes em uma fábrica de calçados que faz a montagem final do produto e depois redistribui para os lojistas. Priscila relata que inicialmente ela deixou a definição dos componentes também sob controle da fábrica, mas depois de algumas produções com qualidades aquém da desejada, passou a definir diretamente quais os componentes a serem utilizados, assumindo as negociações diretas com esses outros fornecedores.

Sobre a etapa intermediária, podemos chamar de detentor da marca a empresa que é responsável pela definição da coleção de produtos, divulgação de marca e definição da distribuição dos produtos.

Quanto aos canais de vendas, os principais são: lojistas multimarca, lojista monomarca e $e$ commerce. O lojista é a ponta final antes do produto chegar ao cliente. Esse lojista pode ser uma multimarca, lojas que agregam diversas marcas em suas prateleiras, exemplo: rede de calçados Mundial, World Tennis e lojistas menores do interior do país,, uma loja própria, na 
qual o detentor da marca é também o proprietário da loja, ou pode ser uma loja monomarca franqueada, na qual o proprietário da loja não é o detentor da marca, este empresário paga pelo uso da marca e deve seguir as diretrizes do detentor da marca - franqueador. Exemplos: Arezzo, Mr. Cat, Sidewalk entre outras.

$\mathrm{Na}$ questão da escolha de canais de venda, a empresária optou por possuir lojas próprias monomarca. Essa era a alternativa que permitia que um produto diferente do padrão pudesse ser entendido pelo cliente e tivesse seu valor agregado percebido. A empreendedora relata que atuar no varejo não era uma vontade, mas foi sim uma necessidade para fazer com que o projeto se concretizasse, entendia que havia um custo nessa ação, mas dessa forma o conceito seria entregue por completo, pois ela teria o controle de como seria a experiência do cliente. Essa ação também se mostrou benéfica, pois permitia aprender com o cliente ao observar sua percepção dos produtos, a forma como consumia e a forma como entendia a marca, assim como realizar ajustes no produto e nos processos. Isso está intrinsecamente ligado a etapa 8 de Monitoramento e Aprendizagem.

A alternativa a essa estratégia era vender o produto para outros lojistas. Avaliou-se a venda para sapataria multimarcas, porém no Brasil, esse tipo de varejo é mais popular para produtos com valores mais baixos, não existia uma sapataria multimarcas focada em sapatos premium. Calçados com valores acima de $\mathrm{R} \$ 300$ costumam ser comercializados em lojas de marca própria em geral em redes de franquias. Já os revendedores de lojas multimarcas de moda, como butiques, adquiririam quantidades limitadas de sapatos, e o produto era apresentado juntamente com muitos outros produtos de categorias diferentes e de diversas marcas. Neste caso, a equipe de venda não conseguiria trabalhar nesta diversidade e os diferenciais do produto Ciao Mao não seriam percebidos. Esse modelo de negócio chegou a ser testado, mas se mostrou limitado quanto ao volume de vendas, os compradores destas lojas, responsáveis pela escolha de marcas e mix de produtos, achava o produto inovador e interessante, mas relatavam que sua equipe de venda considerava o produto trabalhoso para ser explicado para o cliente, optando por apresentar um outro produto, vestido de mesmo valor, por exemplo. Percebia-se que sem a apresentação de uma equipe de venda treinada pela Ciao Mao o cliente não tinha entendimento das possibilidades dos calçados interativos, assim como as qualidades dos materiais e demais valores da marca. 
No decorrer dos anos, a empresa desdobrou seu modelo de negócios, na parte produtiva passou a produzir internamente acessórios e bolsas. Na parte comercial passou a vender para outros lojistas multimarcas, em lojas parceiras com corners da marca, em uma loja virtual própria e no ano de 2016 iniciou seu projeto internacional participando de feiras de negócios da moda em Paris, Nova Iorque e Las Vegas, vendendo para lojistas de mais de 7 países. Esse desenvolvimento dos modelos de negócios, mudaram em diversos aspectos a arquitetura de organização da empresa. Mas no presente trabalho trataremos apenas deste momento inicial das lojas monomarcas próprias.

\section{Lições aprendidas:}

- O empreendedor deve compreender as suas próprias competências e as competências dos demais players da cadeia de valor. A definição de onde irá atuar dentro dessa cadeia e como otimizar as competências dos demais é a principal decisão do empresário neste momento de implementação da estratégia. No caso da Ciao Mao, a empreendedora via sua expertise no meio dessa cadeia de valor, onde ela detinha os conhecimentos de desenvolvimento de produtos e a marca e os seus atributos correlacionados. Ela optou então por não ser a detentora da fábrica, e sim terceirizar a produção.

- Deve-se haver cuidado para não se tomar decisões com excesso de confiança, o empreendedor não pode se sobrecarregar, assumindo papeis demais dentro da cadeia. Isso pode tirar sua atenção da sua principal área e inviabilizar a boa performance nas demais.

- Quando se tem um produto inovador, é necessário treinar o canal de vendas para apresentar o produto adequadamente, caso contrário o produto não terá seu valor percebido, podendo parecer caro, ou seja, o valor percebido sendo menor do que o valor comercializado.

- Iniciar com um modelo de canal de venda não impossibilita a abertura de novos canais no futuro. À medida que a marca e os produtos passam a ser conhecidos pelo público, a necessidade de apresentação pelo canal de vendas direto pode ser substituída ou complementada por novos modelos, como o de vendas online. 


\subsection{Iniciativas Estratégicas}

Essa etapa é o momento de desdobramento das estratégias formuladas em ações concretas para a operação da empresa.

Para conseguir implementar a estratégia de terceirizar a produção Priscila precisou encontrar uma fábrica com o perfil adequado, foi esse um dos motivos para a contratação da assistente de produto. Por esta profissional já ter trabalhado na área, ela tinha contato com fornecedores que poderiam fabricar nas pequenas quantidades iniciais, lembrando que a marca começou com uma única loja, ela não poderia entrar em uma fábrica que fornecesse para uma marca como a Arezzo, por exemplo, pois a Ciao Mao não teria relevância para esse fornecedor.

A empreendedora relata que apesar de entender que essa estratégia de terceirizar era a mais viável, ainda assim era muito desafiadora. A primeira fábrica entregou produtos muito aquém da qualidade desejada, Priscila relata que contou com a expertise da fabricante e aceitou a sugestões de materiais para a fabricação como couro, biqueira e contraforte, porém o produto final entregue era pesado, rígido e desconfortável. Através deste erro, a designer aprendeu que ao trabalhar com um produto inovador, ela necessitaria participar mais ativamente de todas as etapas, inclusive as produtivas, precisando interferir na escolha de cada material, assim como nos processos, para aumentar a qualidade dos produtos.

Priscila relata que nesse momento, não era possível atingir o ideal. Por ser uma empresa nascente, com limitações financeiras, pequenos volumes e produto que fugia dos padrões, não eram muitos fornecedores que se interessavam em fabricar seus produtos. Então nesta etapa ela precisou aceitar os fornecedores disponíveis, e sobrepujar as lacunas que eles tinham, fosse de agilidade de entregas, de qualidade ou de prazos de pagamento. Em diversos momentos, a empresária em diversos momentos, precisou acatar com negociações economicamente desvantajosas, como por exemplo comprar a matéria-prima para o fornecedor ou fazer pagamentos à vista, para conseguir viabilizar os primeiros passos do projeto. 
Ela diz que nesse momento o processo de decisão era limitado, não havia a possibilidade de explorar alternativas e buscar a ideal. Era preciso fazer o melhor com o que estava acessível. Vemos que isto se assemelha bastante ao método flexível de pensamento do design, para Borges (2003) o designer de produto deve adaptar suas ideias aos métodos produtivos viáveis e acessíveis levando em conta: o que as indústrias estão ou não aparelhadas para produzir, se um produto cumpre a sua função da melhor forma possível, a facilidade de manuseio e operação, e sua estética.

Priscila argumenta, que tendo os conhecimentos atuais teria implementado a estratégia de outra forma. Teria por exemplo buscado associações do setor como a ABICALÇADOS (Associação Brasileira da Indústria Calçadista) para buscar parceiros produtivos. Porém ela relata que naquele momento ela desconhecia essas alternativas e precisou realizar decisões com base nas informações limitadas que possuía.

A implementação da estratégia de ter loja própria também foi um desafio. O local foi escolhido pela sua viablidade, pois para iniciar o projeto, ela decidiu aproveitar um imóvel que possuía no bairro de Pinheiros. A outra alternativa era alugar um imóvel, mas uma loja em um bom ponto comercial tinha custos elevados.

Apesar de ter experiência prestando serviços para varejistas, a empreendedora nunca tinha operacionalizado uma loja. Tendo consciência que não tinha os conhecimentos necessários, contratou um consultor de varejo, por acreditar que ele passaria os métodos essenciais para o início da operação. Priscila diz que apesar do currículo extenso do consultor contratado, o conhecimento transmitido foi muito aquém do esperado. Não havia método na consultoria, se limitando a apresentação de ferramentas e opiniões pouco objetivas. Disse que o maior benefício neste serviço foi o contato feito com um sócio desse consultor que já havia sido lojista. A empresária relata que conversar diretamente com uma pessoa que vivenciou os desafios de empreender foi o que mais a auxiliou.

Neste momento, ela ressaltou que na busca por conhecimentos, as tentativas com consultores foram sempre dispendiosas e pouquíssimo efetivas. Ela diz que esse continua sendo um dos grandes desafios no crescimento da empresa, a empresária entende que possui limitações de conhecimento e execução, então acredita na importância de buscar profissionais especialistas que possam suprir essas lacunas de conhecimentos, seja jurídica, industrial, comercial ou de planejamento. Porém as consultorias contratadas pela empresa foram sempre onerosas e 
infelizmente frustradas. Quando questionada se imagina o motivo disso ocorrer de forma recorrentemente, a empresária argumenta que pela sua experiência, os consultores não são realizadores como são os empreendedores, e não se comprometem, ou compreendem, os desafios para concretizar as ações propostas.

Como alternativa ela defende conversar com outros empresários e profissionais experientes. Ela aponta que mesmo através de conversas informais, esses contatos se mostraram muito mais produtivos. A empreendedora defende que é possível se aprender muito ao dividir experiências e que na história da Ciao Mao muitos desses profissionais se empolgaram com o negócio proposto e, mesmo sem serem remunerados, acabaram gerando muitas oportunidades como por exemplo, apresentar para um fornecedor novo ou indicar um funcionário.

\section{Lições aprendidas:}

- Ampliar a rede de contatos no setor que se deseja atuar é uma das estratégias que permitem encontrar os parceiros mais adequados para a implementação e operação do negócio.

- É importante estar aberto a testar, errar e consertar. Incialmente, Priscila optou por deixar a competência de escolha de matéria-prima para as fábricas montadoras dos sapatos, mas ao ver que eles não estavam atingindo o nível de qualidade que ela almejava em seu produto, a empresária rapidamente assumiu esse papel.

- No momento inicial a prioridade é viabilizar o negócio. A impossibilidade de executar o ideal não deve impedir o andamento da empresa. Uma negociação mais onerosa no início pode ser o ponto de partida para uma parceria produtiva, por exemplo. Os ajustes e melhorias da operação da empresa podem vir em uma etapa posterior. É importante saber onde se quer chegar, mas nos momentos inicias de uma empresa é necessário fazer o que é viável, mesmo que este não seja o cenário ideal.

- Projetar um negócio pode ser uma ação solitária, porém operacionalizá-lo não o é. Incluir outros agentes nessa cadeia é essencial, sejam eles funcionário diretos, parceiros ou fornecedores. Essa habilidade de juntar diferentes indivíduos para um objetivo comum é fundamental para um empreendedor de sucesso. 
- Todo profissional tem lacunas de conhecimentos, o mesmo ocorre com uma empresa, quando se torna necessário abrir um novo caminho, por exemplo um novo modelo de vendas. A fonte desse conhecimento pode ser os estudos do próprio empreendedor, pode ser a contratação de um novo funcionário ou a contratação dos serviços de um consultor. Segundo o relato da proprietária da Ciao Mao, esta última opção deve ser tomada com cuidado, uma alternativa sugerida pela empreendedora é buscar trocas de experiências com outros players do mercado, porém podemos colocar uma ressalva de que essa opção é limitada a "boa vontade" desses indivíduos, não sendo uma alternativa confiável se for necessária com recorrência.

\subsection{Monitoramento e Aprendizagem}

O monitoramento externo consiste em identificar e avaliar informações e fatos que podem impactar seu negócio.

A empreendedora e sua equipe sempre se mantiveram atentos aos movimentos de mercado, desde fatores econômicos, até tendências de modas e comportamento. Não há um modelo padrão para isso, mas sim uma busca constante por conhecimento da própria empreendedora. Participar de associações como ABICALÇADOS (Associação Brasileira dos Calçados) e ABEST (Associação Brasileiras dos Estilistas), permitiu um enriquecimento com informações do mercado relativos ao setor.

O monitoramento interno está associado às atividades de acompanhamento e execução da estratégia, observando também os principais indicadores de desempenho da organização. Esse é um dos pontos que no início da empresa menos se deu ênfase, em especial por ser um negócio novo e sem benchmarks. A empreendedora permitiu-se experimentar sem se prender a indicadores numéricos. No decorrer dos anos, a empresa se profissionalizou desenvolvendo relatórios de performance sobre todos os aspectos da empresa.

O aprendizado estratégico consiste na incorporação das lições aprendidas no processo de gestão estratégica. Pedroso (2016) ressalta que isso é importante para lidar com as incertezas inerentes às decisões estratégicas, uma vez que por elas tratarem do futuro são inevitavelmente incompletas e imprecisas. É importante que o aprendizado permita que o 
processo de gestão estratégica seja dinâmico, contínuo e adaptativo, assim como desenvolve a resiliência da organização.

A empreendedora Priscila Callegari sempre se utilizou do aprendizado para reavaliar suas estratégias e adaptá-las. Como designer, ela enxerga esse fluxo contínuo e diz que um projeto nunca está fechado. Ela também valoriza a importância de todos os membros que fazem parte da empresa e da cadeia, sendo necessários que todos compartilhem dos mesmos ideais e objetivos para que um projeto dê certo. Priscila afirma:

"O trabalho de um designer é enxergar toda a cadeia e trabalhar em conjunto com ela. Então o sucesso está em entender quem é o consumidor final e também o fabricante, que está na outra ponta, para suprir as necessidades de cada um. Esse é o grande poder da persuasão que eu aprendi [...]. Você não faz nada sozinho, uma vez que depende de toda essa etapa. Acredito que saber enxergar essas nuances é o segredo do sucesso." (VIVEIROS, 2014, p. 36).

\section{Lições aprendidas:}

- Estar presentes em organizações como associações do setor pode ser uma fonte rica em informações e uma forma de amplia a rede de contatos da empresa.

- O processo de aprendizado é contínuo. O mercado muda com frequência e a empresa precisa se adaptar. Uma empresa de pequeno porte com o processo de tomada de decisão livre de estruturas complexas de poder deve se beneficiar com a agilidade. Aprender com os erros, corrigir e tomar novos caminhos sempre que necessário.

- Quando tratamos de um produto inovador, é essencial estar próximo do cliente e entender suas percepções. Alinhar as expectativas que o criador do produto tem com o valor percebido pelo cliente.

- Entender que uma empresa faz parte de uma extensa e complexa cadeia de valor é a chave para sua operacionalização. Retomando o conceito defendido na introdução do presente trabalho, o empreendedor é um articulador, um líder agregador, ele tem como 
principal função tornar sua visão individual em coletiva, ele deve juntar as partes interessadas e convergir seus esforços a um objetivo comum. 


\section{CONSIDERAÇÕES FINAIS}

O presente trabalho teve como principal objetivo estudar os processos de tomada de decisão de uma empreendedora na sua jornada de criação e gestão de uma empresa, e através deste estudo identificar práticas que pudessem ser benéficas para outros empreendedores.

O caso estudado foi o da empreendedora Priscila Callegari, fundadora da Ciao Mao, empresa de calçados reconhecida pelo seu caráter inovador. A marca já conquistou cinco prêmios de design nacionais e internacionais, participou de diversas bienais de design no Brasil e na Europa. A empreendedora também foi reconhecida pelas suas habilidades de gestão e inovação, sendo considerada pela consultoria internacional KPMG como um dos 20 destaques do empreendedorismo brasileiro em 2013 e pelo SEBRAE como uma das 99 soluções inovadoras do Brasil. A empresa, que vai completar 10 anos de existência em 2017, também teve grande sucesso comercial, contando atualmente com três lojas próprias na cidade de São Paulo e um comércio online, além de estar investindo na sua expansão global. Atualmente a Ciao Mao está presente em mais de 20 pontos de vendas em sete países: França, Itália, Reino Unido, Portugal, EUA, Líbano e África do Sul. Em menos de um ano de início das exportações a empresa ganhou o prêmio Direções da Abicalçados como melhor case de Internacionalização de marca. A marca é uma das poucas brasileiras a ser categorizados como premium ou luxo no mercado internacional, os produtos Ciao Mao são comercializados a um valor médio dez vezes maior do que o valor médio do calçado brasileiro.

Os dados foram obtidos em extensa e profunda entrevista com a empreendedora e através da pesquisa de fontes secundárias. Esses dados foram analisados e confrontadas com as teorias do processo de tomadas de decisões estratégicas.

O estudo permitiu identificar uma série de lições que podem servir de inspiração para a melhoria na tomada de decisões estratégicas para outros empreendedores. Cada uma dessas lições foi concluída a partir da análise de uma experiência real vivenciada no caso estudado e descrita no capítulo de análise de dados. Seguem abaixo as principais lições aprendidas:

1. Não adianta insistir em uma estratégia que não está dando certo só porque ela já foi iniciada. Mesmo havendo resultados de curto prazo, é necessário avaliar a sustentabilidade do modelo de negócio. 
2. O valor que o profissional acredita que seu trabalho tem deve estar em sintonia com o valor percebido pelo cliente. Uma discrepância nesses valores traz frustração ao profissional e insustentabilidade do negócio no longo prazo.

3. O empresário deve repensar seu negócio quando percebe que não está recebendo os resultados esperados. Não apenas do ponto de vista financeiros, mas também se exercer essa atividade não estiver mais alinhado com seus objetivos de vida.

4. Antes de definir qual o escopo de atuação, é importante estudar o mercado, buscar benchmarks e avaliar o cenário em que está inserido. Um modelo de negócio pode funcionar bem em um país e pode não ser replicável em outra realidade.

5. No momento de pesquisa para escolha de escopo de atuação é importante que o empreendedor esteja aberto as oportunidades, ele não precisa fechar o foco. No momento da ideação é importante não perder o senso do possível.

6. O autoconhecimento do empreendedor é fundamental. Se antes da criação de uma empresa, o principal tomador de decisões avalia suas características e objetivos pessoais de forma crítica, essa empresa tem mais chance de se beneficiar dos pontos fortes e mitigar os riscos dos pontos fracos.

7. É benéfico que todo trabalho de pesquisa seja documentado de forma ordenada, mesmo que o escopo final e atuação se altere, os conhecimentos agregados podem gerar insights importantes.

8. Os sócios são os indivíduos com que se dividirá a responsabilidade das tomadas de decisão. A inexistência de afinidade pode causar atritos na operação da empresa e o eventualmente seu insucesso. Deve-se ter cautela na formação de uma sociedade, é essencial dedicar tempo para conhecer os valores desses indivíduos.

9. Tratando-se de um empreendedor com recursos e tempo escassos, é necessário foco para se dominar um assunto. Neste tipo de empresa, normalmente todo o trabalho está concentrado em um único indivíduo que deve ter cautela para não se sobrecarregar.

10. Um empreendedor deve estar atento as informações ao seu redor. Podem haver indícios de uma oportunidade de negócio em situações inesperadas. Porém é 
essencial que um profissional competente não se paute apenas por insights, o estudo do mercado e uma pesquisa aprofundada devem corroborar com essas ideias.

11. Quando definido o campo de atuação, é importante aprofundar o entendimento deste mercado. É importante entender as necessidades que um produto deve saciar e como funciona a sua cadeia de valor. Nenhum produto é isolado, ele sempre tem diversos ângulos a serem analisados. Um empreendedor deve estar atento a saciar estas diversas necessidades concomitantemente.

12. A região de atuação de uma empresa não pode ser definida pensando apenas em aspectos mercadológicos, deve se considerar questões de viabilidade de operação. O local comercialmente ideal pode ser excessivamente caro, assim sendo, o importante é achar uma alternativa que harmonize o potencial de vendas com os recursos disponíveis.

13. Não adianta dar uma solução, se você não souber com clareza qual é o problema. É importante entender como os problemas eram resolvidos no passado e como estão sendo resolvidos agora. O designer e o empreendedor devem ser profissionais treinados para ter a capacidade de identificar necessidades não atendidas ou mal atendidas e a partir deste conhecimento gerar soluções criativas para saciá-las.

14. Toda empresa precisa ter uma expectativa do futuro para tomar decisões estratégias, porém o futuro é sempre incerto e o risco é inerente. Neste contexto, entender o passado e observar o presente são as formas que um profissional tem de projetar um futuro esperado.

15. Inovar implica ter uma ideia original. Pode-se questionar então de onde vêm esse insight criativo de um designer ou empreendedor. Priscila argumenta que "original tem a ver com origem", devemos então buscar a origem do que queremos criar e não copiar um modelo pronto do concorrente.

16. O que pode ser entendido como restrição para alguns pode ser visto como oportunidade para outros. Uma barreira econômica protecionista pode ser 
considerada um problema para um importador, enquanto pode ser vista como uma oportunidade para um produtor local.

17. Empreender é uma atividade que demanda grande dedicação de tempo e recursos. A atividade profissional interseciona com a vivência pessoal e familiar. Desta forma, os impactos da criação de uma empresa não conseguem ser isolados, a harmonização dessas duas esferas é necessária.

18. É importante que um empreendedor tenha uma rede de contatos com que possa discutir suas ideias e melhorar a sua tomada de decisão. É recomendável que essa rede contenha pessoas que entendam de fato a realidade empresarial para que sejam conversas construtivas e não palpites. Quando não há indivíduos com este perfil próximos ao empreendedor, é interessante buscar caminhos alternativos, como instituições de apoio a empresários e cursos na área em que se deseja atuar.

19. Muitos cursos tem um formato que visa o desenvolvimento de habilidades que melhoram a eficiência das atividades, mas não a eficácia. Pessoas eficientes desenvolvem bem um processo e as eficazes tomam melhores decisões. Ou seja, para se chegar a um destino desejado, mais importante que andar rápido é saber para onde andar. Para inovar devemos buscar melhorias disruptivas, descobrir novos caminhos, novos meios de transportes ou atalhos antes não explorados.

20. O processo de criação de uma ideia inovadora tem que ter um amadurecimento. Ela não pode ser executada precipitadamente. Uma decisão estratégica tem que ser sedimentada, tem que ser discutida com outras pessoas. Tentar destruir uma ideia, possibilita construir argumentos para defendê-la.

21. A criação e operação de uma empresa não se faz sozinho, contar com um bom time é fundamental. É importante buscar profissionais que complementem as habilidades que o empreendedor não possui ou não tem tempo de executar.

22. Em relação a estrutura de poder, o empreendedor tem a vantagem de ser o tomador das decisões estratégicas. Sem uma hierarquia complexa e sem superiores a quem se reportar, suas decisões podem ser realizadas de forma ágil e livre. Essa liberdade pode ser paralisante para alguns, pois não há com quem dividir as responsabilidades da tomada de decisão, os riscos são assumidos integralmente por 
este indivíduo. Neste contexto, é essencial estruturar bem as ideias, para que o empreendedor se sinta tranquilo em assumir os riscos envolvidos.

23. O perfil do empreendedor é fundamental para o seu sucesso. Por não precisar se reportar a ninguém, há o risco do profissional perder o foco e não ter exigência de excelência nas suas atividades. Assim como é importante ter resiliência para conseguir sobrepujar os erros cometidos e desafios impostos na trajetória da criação de uma empresa.

24. No processo de inovar: o excesso de zelo, a busca por mitigar riscos e a expectativa de taxas de retorno concretas podem paralisar a criação de uma empresa. Inovar é assumir riscos, mas gerir uma empresa é ser racional com a sua capacidade de gerar lucros com os recursos disponíveis. É necessário que o empreendedor balanceia esses dois pensamentos: viabilizar a existência da empresa sem perder o senso do possível.

25. No momento de criação de uma organização, é comum que os valores da empresa não estejam declarados de forma explicita. No caso de um empreendedor, normalmente a empresa é reflexos dos seus próprios valores.

26. A criação de missão e visão de uma organização não precisam ser explicitadas desde o seu início. Após um tempo de atividade, a missão e visão podem ser definidas com mais clareza, refletindo a forma como a empresa age para resolver os seus problemas e sabendo onde ela deseja chegar.

27. No processo de empreender, nota-se que o resultado financeiro não é a única recompensa, e às vezes nem é a principal recompensa para este profissional, a realização pessoal em uma atividade que atenda seus valores parece ser o resultado almejado por esse indivíduo.

28. O conceito de usar o preço como um balizador de posicionamento pode não ser sustentável. É recomendável que a precificação do produto parta da qualidade, sendo uma consequência do que o produto oferecesse. A solução não deve ser apenas para o cliente, deve saciar também os demais participantes da cadeia de valor assim como considerar os impactos sobre o meio ambiente. 
29. Definir o público alvo e entender este público é fundamental. Isso não precisa ser feito com fórmulas padrão como definição de faixa etária ou gênero. $\mathrm{O}$ importante é encontrar um público que veja valor no produto que a empresa deseja oferecer e que esteja disposto a pagar por ele.

30. Deve haver coerência entre a proposta adotada por uma empresa e a execução realizada. É importante que as ações da empresa sejam coerentes com a estratégia proposta para que ela cresça de forma sustentável e tenha confiabilidade no mercado.

31. A definição de onde irá atuar dentro dessa cadeia e como otimizar as competências dos demais players são as decisões mais importantes do empresário no momento de implementação da estratégia. O empreendedor deve compreender as suas próprias capacidades e as competências dos demais participantes da cadeia de valor.

32. Deve-se ter cuidado para não se tomar decisões com excesso de confiança, o empreendedor não pode se sobrecarregar, assumindo papéis demais dentro da cadeia. Isso pode tirar sua atenção da sua principal área e inviabilizar a boa performance nas demais.

33. Quando se tem um produto inovador, é necessário treinar o canal de vendas para apresentar o produto adequadamente, caso contrário o produto não terá seu valor percebido.

34. Iniciar com um modelo de canal de venda não impossibilita a abertura de novos canais no futuro. A medida que a marca e os produtos passam a ser conhecidos pelo público, a necessidade de apresentação pelo canal de vendas direto pode ser substituída ou complementada por novos modelos.

35. Ampliar a rede de contatos no setor que deseja atuar é uma das estratégias que permitem encontrar os parceiros mais adequados para a implementação, operação e expansão do negócio.

36. A impossibilidade de executar o ideal não deve impedir o andamento da empresa. Uma negociação mais onerosa no início, pode ser o ponto de partida para uma parceria produtiva futura. Os ajustes e melhorias da operação da empresa podem 
ser realizadas em uma etapa posterior. É importante saber onde se quer chegar, mas nos momentos inicias de uma empresa é necessário fazer o que é viável, mesmo que este não seja o cenário ideal.

37. Projetar um negócio pode ser uma ação solitária, porém operacionalizá-lo não é. Incluir outros agentes nessa cadeia é essencial, sejam eles funcionário diretos, parceiros ou fornecedores. Essa habilidade de juntar diferentes indivíduos para um objetivo comum é fundamental para um empreendedor de sucesso.

38. Todo profissional tem lacunas de conhecimentos, o mesmo ocorre com uma empresa. A fonte de um novo conhecimento podem ser os estudos do próprio empreendedor, pode ser a contratação de um novo funcionário ou a contratação dos serviços de um consultor.

39. Estar presentes em organizações como associações do setor pode ser uma fonte rica em informações e uma forma de amplia a rede de contatos da empresa.

40. O processo de aprendizado é contínuo. O mercado muda com frequência e a empresa precisa se adaptar. Uma empresa de pequeno porte com o processo de tomada de decisão livre de estruturas complexas de poder deve se beneficiar com a agilidade. Aprender com os erros, corrigir e tomar novos caminhos sempre que necessário.

41. Quando tratamos de um produto inovador, é essencial estar próximo do cliente e entender suas percepções. Assim realizar adaptações sempre que necessário.

Avaliando o caso e as lições aprendidas na sua análise, vemos que uma empresa empreendedora de pequeno porte tem desafios diferentes de uma grande corporação. Ao tratarmos do processo de tomada de decisão, vemos que o empreendedor tem a vantagem de ser livre nas suas escolhas, porém tem o desafio de ter que assumir os riscos integralmente.

Pelo caso estudado concluímos a importância de um grande estudo prévio da área em que se deseja atuar, assim como um autoconhecimento do empreendedor das suas habilidade e recursos antes da tomada de importantes decisões estratégicas.

Analisou-se também a importância de entender a cadeia de valor em que a empresa atuará e como ela se relaciona com os diversos elos dessa cadeia. As tomadas de decisões devem 
considerar os impactos causados a cada um desses elos. Uma das grandes razões do sucesso da Ciao Mao é a habilidade de Priscila Callegari de entender que todos os participantes são impactados pelas ações da sua empresa, positiva ou negativamente, sejam clientes, funcionários diretos, fornecedores ou mesmo o meio ambiente. A existência de um negócio deve buscar trazer benefício para todos os participantes da cadeia, o empreendedor precisa ter uma visão com empatia por todos esses agentes. Por sua formação de designer, a empresária enxerga que a inovação não deveria estar isolada no desenho do produto, mas sim na identificação de oportunidades de melhorias em cada uma das instâncias do projeto. Dessa forma, é necessário pensar em como realizar melhor cada uma dessas atividades, para que haja geração de valor para todos envolvidos e consequentemente para o produto final e a empresa. Essa capacidade de entender a indústria, achar soluções inovadoras e articular os envolvidos para um objetivo comum, é um dos grandes diferenciais dessa empreendedora.

Ela tem também as habilidades de uma líder agregadora. Podemos concluir que um empreendedor de sucesso entende que não pode realizar nada sozinho, ele faz parte de uma rede, e a tomada de decisões estratégias deve envolver e otimizar as capacidades dessa rede, tanto no momento de estudo do problema, buscando opiniões diversas, como na hora da execução, buscando os participantes certos para a resolução de cada situação. 


\section{LIMITAÇÕES E SUGESTÕES PARA ESTUDOS FUTUROS}

O presente trabalho foi feito em profundidade na empresa Ciao Mao e as lições aprendidas podem servir de inspiração para outras organizações. Porém é importante ressaltar que por se tratar de um estudo de caso único em profundidade, ele é limitado. Por mais que seja baseado em situações reais, ele não pode ser considerado um comportamento padrão de um grupo.

O conhecimento prévio da empresa pelo autor possibilitou uma pesquisa aprofundada do caso, porém é importante não desconsiderarmos a possibilidade de viés no estudo, a análise de dados pode ter sofrido influência de um pré-julgamentos decorrentes desse conhecimento prévio do autor.

Em estudos futuros, indica-se a possibilidade de realização de pesquisas qualitativas e quantitativas com outros empreendedores, de forma a validar as principais conclusões encontradas neste trabalho.

Pode-se avaliar também se há convergências e divergências entre empreendedores inovadores de diferentes áreas. Neste caso, foi uma empreendedora da indústria criativa, especificamente de um artigo de moda. Se comparada com um empreendedor inovador da área de tecnologia, por exemplo, quais semelhanças e diferenças podem ser encontradas nos seus processos de tomada de decisão.

Há a oportunidade também de estudar com mais profundidade as contribuições que as teorias de design podem trazer para administração. Na revisão bibliográfica realizada para este presente trabalho, pode-se identificar indícios de vários pontos de contribuição. $\mathrm{O}$ próprio conceito de design thinking vem sendo utilizados como ferramenta de geração de inovação nas empresas, temos ainda conceitos como o do design estratégico com potencial de aprofundamento e avaliação de utilização prática em organizações. 


\section{REFERÊNCIAS}

ACKOFF, Russel L. A empresa democrática: métodos conceitos e técnicas para renovar a gestão com sucesso. Lisboa: Difusão Cultural, 1998.

ALMEIDA, Martinho Isnard Ribeiro. Manual de planejamento estratégico: desenvolvimento de um plano estratégico com a utilização de planilhas do Excel. 3. ed. São Paulo: Atlas, 2010.

AMBROSE, Gavin; HARRIS, Paul. Design Thinking. 1. ed. São Paulo: Bookman, 2011.

AZEVEDO, Marilena Coelho de; COSTA, Helder Gomes. Métodos para avaliação de postura estratégica. Caderno de Pesquisas em Administração. São Paulo. v.08. n². abril/junho. 2011.

AREZZO \& CO. A Companhia. Disponível em: http://www.arezzoco.com.br/show.aspx?idCanal=3SpgX/Ij1YkyuFCjWINUfA==. Acessado em: 25/03/2013.

ASSUMPÇÃO, Vera Melaragno. Estudo de caso CIAO MAO: Plano de comunicação. São Paulo. 2010. Dissertação (Pós-graduação Marketing) - ESPM.

BARLACH, Lisete. A criatividade humana sob a ótica do empreendedorismo inovador. São Paulo, 2009. Tese (Doutorado) - Instituto de Psicologia da Universidade de São Paulo.

BARNEY, Jay; HESTERLY, William S. Administração Estratégica e Vantagem Competitiva. São Paulo: Pearson. 2008.

BORGES, Adélia. Designer não é Personal Trainer. 2 ed. - São Paulo : Rosari, 2002.

BONO, Edward. Os seis Chapéus do Pensamento. 1 ed. - São Paulo: Sextante. 2008

BUCHANAN, Leigh; O’CONNEL, Andrew. Uma breve história da tomada de decisão.

Revista Harvard Business Review. Publicada em Janeiro de 2006. Disponível em: aljmartins.hostmach.com.br/ist/dis/sad/material/tomada_decisao.pdf. Acessado em 23/05/2017.

CALlegARI, Priscila. Apresentação da Ciao Mao - Concurso IDEA/BRASIL. São Paulo, 2008. 
CARDOSO, Rafael. Design para um mundo complexo. São Paulo: Cosac Naify, 2013.

CIAO MAO. Disponível em: www.ciaomao.com. Acessado em: 23/07/2017.

DUARTE, Guilherme Callegari Leme. Estudo de caso: Reflexões sobre as estratégias de expansão de uma marca de calçados inovadora a partir do refinamento do seu modelo de negócios. São Paulo. 2013. Monografia (MBA Varejo) - Fundação Instituto de Administração - FIA.

DRUCKER, Peter. The Essential Drucker. New York, Harper Business, 2001

FERLAUTO, Claudio. O tipo da gráfica: uma continuação. 1. Ed - Rosari, 2002.

FISCHMANN, Adalberto Américo; ALMEIDA, Martinho Isnard Ribeiro. Planejamento estratégico na prática. 2. ed. 20. Reimpr. São Paulo : Atlas, 2011.

FLICK, Uwe. Uma introdução a pesquisa qualitativa. 2. Ed. - Porto Alegre: Bookman, 2004.

FOLHA DE S. PAULO. Salto Mortal. Disponível em: http://www1.folha.uol.com.br/fsp/folhatee/fm2206200916.htm. Publicado em: 22/06/2009. Acessado em: 23/07/2017

G1. Histórias contadas pelas marcas Diletto e Do Bem vão parar no Conar. 15 de novembro de 2017. Disponível em: http://g1.globo.com/economia/midia-emarketing/noticia/2014/11/historias-contadas-pelas-marcas-diletto-e-do-bem-vao-parar-noconar.html. Acessado em: 25/06/2017

GONÇALO, Cláudio Reis et al. Storytelling para a Identificação de Estratégia como Prática. Revista Ibero-Americana de Estratégia, 12(1), 2013 p. 131-153.

GORB, Peter. The Business of Design management. Copenhagen: Elsevier Ltd. 1986.

GRANT, Robert M. Strategic planning in a turbulent environment: evidences from the oil majors. Strategic Management Journal. 24 (6), 491-517.

HAYASHI, Daniel Tomoki. Planejamento estratégico em uma pequena empresa: um estudo de caso na empresa Ciao Mao. São Paulo. 2013. Trabalho de Conclusão de Curso Pós-graduação em Administração Estratégica - Fundação Instituto de Administração (FIA).

HAYASHI, Daniel Tomoki, RAMOS, Heidy Rodriguez. Inovação através do Design: Um estudo de caso da empresa Ciao Mao. II Simpósio Internacional de Gestão de Projetos (II 
SINGEP) e o I Simpósio Internacional de Inovação e Sustentabilidade (I S2SI), v. 1, p. 1-20, 2013.

HAYASHI, Daniel Tomoki, ALMEIDA, Martinho Isnard Riberio. Definição de atributos estratégicos para diferenciação competitiva no mercado calçadista brasileiro: um estudo de caso da empresa Ciao Mao. III Encontro do Mestrados Profissionais de Adminsitração (III EMPRAD) v. 3. 2016.

HUANG, Xueli. Strategic decision making in Chinese SMEs. Chinese Management Studies. v.3, n.2, 2009, pp. 87-101.

IEMI. Brasil Calçados 2012: Relatório Setorial da Indústria de Calçados do Brasil. Abicalçados (Associação Brasileira das Indústrias de Calçados).

KIM, W. Chan; MAUBORGE, Renné. Blue Ocean Strategy - Harvard Business School Publishing Corporation, 2005.

KRAKAUER, Patrícia Viveiros de Castro. A utilização das informações do ambiente no processo de decisão estratégica: estudo com empresários brasileiros e americanos de pequenas e médias empresas. São Paulo, 2011. Dissertação (Mestrado) - Universidade de São Paulo.

LAFLEY, Alan G.; MARTIN, Roger. Playing to win: How strategy really works. Boston: Harvard Business Review Press. 2013.

MADEIRA, Adriana Beatriz. Internacionalização do varejo: um estudo com empresas brasileiras por meio de análise de conteúdo. São Paulo, 2009. Tese (Doutorado) Departamento de Administração da Faculdade de Economia, Administração e Contabilidade da Universidade de São Paulo.

MARTINS, Daiana R. Processo de decisão e empreendedorismo: Um estudo com empreendedores da região oeste de Santa Catarina. São Leopoldo, 2013. Dissertação (Mestrado profissional em Administração) - Fundação Padre Leopoldo.

MINTZBERG, Henry. Power in and around organization. Englewood Cliffs, NJ: Prentice Hall, 1983. 
MORILHAS, Leandro José. $\mathbf{O}$ estágio emergente das práticas ambientais no desenvolvimento de produto das organizações inovadoras: um estudo exploratório. São Paulo, 2007. Dissertação (Mestrado) - Departamento de Administração da Faculdade de Economia, Administração e Contabilidade da Universidade de São Paulo.

MONTGOMERY, Cynthia A. O estrategista: seja o líder que sua empresa precisa. (tradução Liliana Negrello); Rio de Janeiro; Ed. Sextante, 2012.

MOZOTA, Briggite B. de; KLÖPSCH, Cássia; COSTA, Filipe C. Xavier da. Gestão do Design: Usando o Design para Construir Valor de Marca e Inovação. Porto Alegre: Allworth Press, 2003. 309 p. (1).

MOZOTA, Brigitte Borja de. Design and competitive edge: A model for design management excellence in European SMEs1. Design Management Journal. Boston, p. 88-103. 14 jun. 2010.

O ESTADO DE S. PAULO. 'Às vezes, acadêmicos subestimam a estética', diz criador da Osklen. 22 de outubro de 2012. Disponível em: http://www.estadao.com.br/noticias/impresso,as-vezes-academicos-subestimam-a-esteticadiz-criador-da-osklen,949087,0.htm. Acessado em: 15/03/2013

OECD. Manual de Oslo 3 ed. (tradução Flavia Gouveia), 1997.

PEDROSO, Marcelo C. Modelo de negócios e suas aplicações em administração. São Paulo, 2016. Tese (Livre-Docência) - Faculdade de Economia, Administração e Contabilidade da Universidade de São Paulo.

PORTER, Michael E. Estratégia Competitiva. Rio de Janeiro: Campus, 1980.

SALONER, Garth; SHEPARD, Andrea; PODOLNY, Joel. Strategic Management. New York: John Wiley and Sons. 2001.

SEBRAE. Taxa de Sobrevivência de Empresas no Brasil. Brasília, 2011. Coleção Estudos e Pesquisa - Unidade de Gestão Estratégica do Sebrae Nacional - Núcleo de Estudo e Pesquisa.

SIMON, Herbert. A razão nas coisas humanas. Lisboa: Gravida, 1989. 
SMITH, Julia. Strategies for Start-Up. Long Range Planning, v.31, n. 6, 1998, pp. 857 872.

SOLINO, Antônia da S.; El-Aouar, Walid A. O processo de tomada de decisões estratégicas: entre a intuição e a racionalidade. Caderno de Pesquisas em Administração, São Paulo, v. 08, nº 3, julho/setembro, 2001.

STONER, James A. F; FREEMAN, R. Edward, Administração. Rio de Janeiro: PrenticeHall do Brasil, 1992.

TERENCE, Ana Cláudia Fernandes. Planejamento estratégico como ferramenta na pequena empresa: desenvolvimento e avaliação de um roteiro prático para o processo de elaboração do planejamento. São Carlos, 2002, 211p. Dissertação (Mestrado) - Escola de Engenharia de São Carlos, Universidade de São Paulo.

XAVIER, Wladmir Gonçalves; CACELLIER, Everton Luiz Pelizzaro de Lorenzi. Atividade de monitoramento de empresas de startup de base tecnológica na indústria de turismo. Análise, Porto Alegre, v.19, n.2, 2008. 
APÊNDICE

APÊNDICE 1 - Roteiro semisestruturado de entrevista com a Priscila Callegari APÊNDICE 2 - Autorização para uso de nome 


\section{APÊNDICE 1 - ROTEIRO DA ENTREVISTA COM PRISCILA CALLEGARI}

A entrevista foi feita presencialmente no dia 06 de julho de 2017, teve a duração de duas horas e meia e foi integralmente gravada para posteriormente ser transcrita pelo autor. $\mathrm{O}$ roteiro abaixo foi construído de forma semiestruturada, servindo como um guia para a condução da entrevista.

\section{$\underline{\text { Introdução }}$}

Priscila, faremos uma entrevista semi-estruturada, ou seja, teremos um questionário como linha condutora, mas não são perguntas fechadas e poderemos nos aprofundar em temas que julgarmos relevantes no decorrer da entrevista.

Neste momento estou no papel de pesquisador, me manterei isento de opiniões e pressuposições sobre os fatos que discutiremos.

O objetivo do trabalho é entendermos o processo decisório de um empreendedor. Não temos intenção de explorar o processo de decisões corriqueiras, de nível operacional ou tático, mas sim as tomadas as decisões estratégicas, aquelas que definem o direcionamento da empresa e causam impactos de longo prazo.

O importante neste contexto é como se deu a decisão, como foi o processo, não havendo a necessidade de detalhar a decisão tomada em si, ou dados específicos da empresa.

Para estruturar o trabalho e a entrevista, optamos por seguir os 8 passos iniciais do modelo de desenvolvimento da estratégia sugerido pelo Professor Marcelo Caldeira Pedroso na sua tese de livre docência na FEA-USP em 2016.

Por se tratar de um tema longo, caso haja necessidade podemos dividirmos a entrevista em duas partes.

Alguns temas serão recorrentes e haverá interesecções. Buscaremos seguir a sequência sugerida das etapas e caso haja repetição definiremos a abordagem para cada caso.

\section{$\underline{\text { Entrevista }}$}


Para a criação da estratégia de uma empresa, entende-se que há várias etapas: análise interna, externa, definição de proposta de valor, campo de atuação, etc.

- Qual foi a primeira decisão que você tomou para empreender nesse novo negócio?

- Você tinha uma outra empresa. Quando você decidiu fechá-la você já sabia que abriria um novo negócio?

- Você já tinha decidido em que área atuaria e daí partiu para análise externas e internas? Ou o contrário?

Assim sendo vamos começar pelo tópico Escopo de atuação.

\section{1) ETAPA 4: Escopo de Atuação}

Está relacionada a decisões estratégias em quatro principais questões: (1) setor de atuação, (2) definição de clientes atuais e futuros, (3) região de atuação e (4) linha de produtos e serviços.

Respondo a questão (1): qual o setor de atuação da organização e em quais segmentos, ou em quais atividades a empresa pretende atuar?

- Como você chegou a decisão de ter uma marca de sapatos? E não de roupas ou outro produto? Habilidade pessoais? Vontade?

- Você cogitou outras alternativas de áreas de atuação?

- Como você chegou a decisão de atuar em São Paulo? Você avaliou expandir o negócio neste início? Já tinha planos de expansão claros neste momento? E em São Paulo por que o bairro de Pinheiros e posteriormente como foi a decisão de abertura das demais lojas?

- Como você definiu quais linhas de produtos trabalharia? Apenas feminino e não masculino e infantil por exemplo. Quando você decidiu entrar nessas outras linhas? Como se deu esse processo? E bolsas? Foi para uma oportunidade ou foi uma estratégia planejada?

2) ETAPA 2 - Análise Externa 
Essa análise objetiva identificar: as questões relevantes e variáveis de decisão relacionadas ao ambiente externo; e as principais oportunidades, os riscos (ou ameaças) e as restrições (legais, sociais, ambientais,...) advindas do ambiente externo. Tradicionalmente essa análise é realizada em três níveis, que consistem nos ambientes geral, setorial e competitivo.

- Como você avaliou o ambiente geral, setorial e competitivo? Através de leituras, viagens, conversas com especialistas (Senai, Sebrae, diretores de empresas)?

- Você destacaria alguma dessas ações como mais relevantes?

- Houve um momento de insight?

- Você descartaria alguma dessas ações? Acha que te fez perder tempo ou te direcionou para o lado errado?

- Quanto tempo você dedicou para cada uma dessas ações?

- A questão econômica (ter verba) foi relevante na decisão de que ação tomar para buscar as informações necessárias para a análise externa?

- Você poderia citar alguma restrição legal, social, ambiental ou econômica que te ajudou a tomar uma decisão estratégica? E como você soube dessa restrição?

- Você documentava as informações e idéias que surgiam desses estudos? Você dividia essas informações com alguém?

- Que práticas você indicaria para outros empreendedores nessa etapa de analisar o ambiente externo?

3) ETAPA 3: Análise Interna

Essa é uma etapa de análise objetiva sobre as questões relevantes e as variáveis de decisão relacionadas ao ambiente interno da organização, seus pontos forte e vulnerabilidades. Pedroso (2016) coloca que alguns desses pontos são: processos e atividades, produtos e serviços oferecidos, governança corporativa, e contexto organizacional (estrutura organizacional, a cultura e a estrutura de poder). 
- Você contou com uma equipe para fazer essa transição (fechamento e abertura de empresa)? Funcionários? Consultores? Parentes?

- Como se deu a seleção dessas pessoas?

- Qual a estrutura de poder? Havia uma estrutura de poder para a tomada de decisões?

- A possibilidade de inovar em uma empresa própria te motivou a empreender? Qual a importância de ser a detentora da tomada de decisão neste processo? Assumir riscos?

- Considerando estes aspectos internos da empresa: equipe, acesso a capital, conhecimentos. Quais você considera que era os pontos fortes da empresa que você estava criando? E quais as vulnerabilidades?

- Você tinha estruturado um processo de governança corporativa? Controles financeiros, contratos com fornecedores, etc?

4) ETAPA 1 - Intenção estratégica

Essa é a etapa que fala se de missão, visão e valores.

- Você estava familiarizada com esses conceitos quando estava criando a empresa?

- Se sim, você definiu eles bem? Deixou eles escritos e divulgou eles para os stakeholders?

- Se não, explicarei brevemente o que são:

Conforme Pedroso (2016) coloca:

“A missão expressa o propósito dominante da organização. Ela responde as seguintes questões: por que a empresa existe? Qual é sua principal contribuição aos consumidores e à sociedade? Se a empresa não existisse, ou deixasse de existir, o mundo seria diferente? Os valores organizacionais são crenças básicas sobre o que é importante para a empresa. Uma declaração dos valores responde as seguintes perguntas: o que é importante para a empresa? Quais são as crenças básicas da organização? 
A visão contempla a posição futura desejada para a organização, em torno do qual seus líderes e colaboradores devem focar a atenção e os esforços organizacionais. A visão responde as seguintes questões: o que a empresa deseja ser no futuro? Qual é sua posição almejada?”

- Tendo isso em vista, você acredita que houve uma definição destas questões no momento de criação da empresa, mesmo que sem estar estruturada?

- Como você definiu esses pontos? Sustentabilide, design original, brasilidade, curadoria e cocriação, qualidade e conforto.

- Os pontos então vieram de uma análise externa e não de pensamentos internos próprios?

(essa etapa se sobrepõe a ETAPA 2 de Análise Externa)

- Você pediu auxílio profissional ou de alguma outra pessoa?

- Onde buscou informação?

- Você criou um leque de alternativas e dentro dessas você fez a escolha?

- Qual o critério de decisão dadas as alternativas?

- Quanto tempo demorou desde que começou a pensar sobre o assunto até a decisão final?

- O quão disposta você estava a mudar a sua decisão no meio do processo? Houve algum momento em que você mudou uma decisão que acreditava já estar definida? Foi bom ter mudado ou você se arrependeu?

- O quanto esses pontos têm a ver com as suas crenças pessoais? Você enxerga uma dissociação da empresa ou é praticamente uma réplica dos seus valores pessoais?

- Você acredita que ter a definição clara das intenções estratégicas te auxiliou na tomada de decisões futuras para a empresa? Retomaremos este assunto nas próximas etapas.

\section{5) ETAPA 5: Posicionamento Estratégico}

O trabalho de Pedroso (2016) descreve essa etapa tendo dois conjuntos de decisões. Um é o posicionamento competitivo, que determina que posição da organização e sua marca perante os seus concorrentes. 
O segundo define o conjunto de benefícios a ser entregues aos clientes por meio de produtos e serviços da empresa, levando em consideração o patamar de preço. O autor levanta uma série de questionamentos que ajudam a definir a proposta de valor para a empresa: "qual a tarefe a ser feita? Em outras palavras, quais os problemas importantes ou necessidades dos clientes devem ser resolvidos? Quais os benefícios? De que forma os produtos e serviços oferecidos resolvem o problema dos clientes? Quais são os diferenciais da organização? Ou seja, o que a organização faz diferente ou melhor que seus concorrentes?" (Pedroso, 2016, p. 111).

- Como você chegou na definição de posicionamento da marca perante seus concorrentes. No quesito patamar de preços? Você já tinha a intenção de trabalhar com um posicionamento premium? Você avaliou a possibilidade de trabalhar com um preço mais baixo?

- Havia uma definição de faixa etária? Ou hábitos de consumo? Lifestyle?

- Como você realizou a análise da concorrência?

- Como você chegou no posicionamento de proposta de valor da empresa. Como você chegou a decisão em investir em design original?

- Como você chegou na decisão de trabalhar com calçados confortáveis e de qualidade? Você avaliou a predisposição dos clientes de pagarem por um produto com essas qualidades?

- Como você chegou no conceito de sapatos interativos? Você enxergou isso como uma inovação?

- E a questão da perecibilidade dos produtos de moda. A ideia de design original e possibilidade de interatividade quebra esse ciclo, assim como gera melhorarias de performance em relação a margem de preço, já que os produtos não precisam ser liquidados a cada coleção. Você tinha traçado esse planejamento ou foi um upside que surgiu após a definição da proposta de valor?

- Sobre a sustentabilidade. Como ele se tornou um fator importante na definição da empresa?

6) ETAPA 6: Modelo de negócio

Nessa etapa deve-se definir a forma como a organização será estruturada para criar, entregar e capturar valor. 
- Para suas tomadas de decisões você sempre avalia a cadeia de valor? Etapas e pessoas envolvidas?

- Você estudou a cadeia de valor da indústria calçadistas. Desde a fabricação até a venda. Como você decidiu onde atuar? Como você decidiu que a Ciao Mao deveria atura no papel intermediário de criação de produtos e controle da marca? Aptidões pessoais? Verba?

- Como você chegou na decisão de não ter uma fábrica de sapato? Você cogitou a alternativa de ter uma fábrica? O que pesou mais nesta decisão? A questão monetária pesou mais? A questão logística/operacional? O conhecimento pessoal? Os riscos?

- Como você chegou a decisão de atuar no varejo? Ter uma loja própria? Você calculou taxas de retorno e custos $\mathrm{x}$ ganhos? $\mathrm{O}$ auxílio do consultores for importante para a tomada de decisão? Como você chegou nestes consultores? Por que decidiu contratá-los? Houve auxílio de fato?

- Outros modelos de negócio surgiram, como o e-commerce e a exportação. A decisão por implementá-los se deu de forma semelhante a decisão do modelo de negócio original? Ou o fato da empresa já estar estruturada mudou a dinâmica? Você contou com outros recursos para a tomada de decisão?

7) ETAPA 7: Iniciativas Estratégicas

Nessa etapa o objetivo é identificar e selecionar as iniciativas e projetos estratégicos que atendem a necessidade da estratégia formulada. É o momento de desdobramento das estratégias formuladas.

- Para a questão produtiva. Havia uma decisão em terceirizar. Como se buscou fornecedores? Como se decidiu por esses fornecedores? Houve alguma análise formal? Havia uma gama de alternativas?

- Abertura de lojas. Como foi definida a abertura de lojas, tanto a primeira como a segunda e a loja de shopping? Seguia alguma análise formal? Fez projeções financeiras?

- Como você se preparou para a operação? Como foi feita a contratação de equipe inicial? 
8) ETAPA 8: Monitoramento e aprendizagem

O monitoramento externo consiste em identificar e avaliar informações e fatos que podem impactar seu negócio.

- Houve uma continuação de monitoramento e aprendizagem depois das decisões iniciais? Você considerou alterar decisões já tomada frente a novas situações?

- Como você realiza esse processo de monitoramento e aprendizagem? Realiza cursos? Leitura? Conversa com outros players do mercado? Através da sua própria equipe? Novos funcionários? Consultores?

\section{OUTROS ASSUNTOS}

- Pela sua experiência, você acredita que toma decisões de forma diferente de outros empresários ou executivos de grandes empresas? Como?

- Como a sua formação educacional afeta essa forma de tomada de decisão?

- O que você considera mais importante para um empreendedor na hora de tomar uma decisão?

- Existe alguma decisão que você tomaria de forma diferente hoje em dia? 


\section{APÊNDICE 2 - AUTORIZAÇÃO PARA USO DE NOME}

São Paulo, 22 de dezembro de 2017

Eu, Priscila Callegari Leme Duarte, autorizo a divulgação do meu nome e da empresa Ciao Mao na dissertação de mestrado de título "Processo de decisão estratégica de uma empresa empreendedora: um estudo de caso da empresa Ciao Mao" de autoria de Daniel Tomoki Hayashi.

As informações contidas na dissertação relativas a empresa Ciao Mao são de conhecimento público (publicadas em diferentes meios de comunicação) ou foram obtidas na entrevista realizada no dia 07 de junho de 2017.

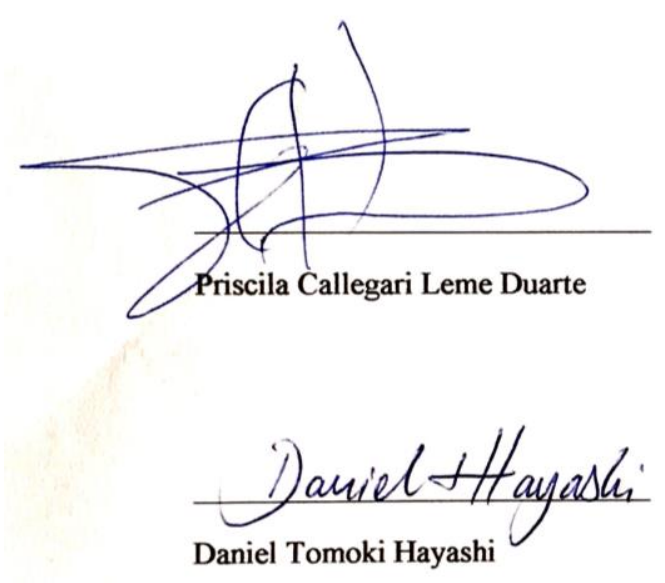

